\title{
A review of the distribution of particulate trace elements in urban terrestrial environments and its application to considerations of risk
}

\author{
S. Charlesworth $\cdot$ E. De Miguel $\cdot$ A. Ordóñez
}

\begin{abstract}
We review the evolution, state of the art and future lines of research on the sources, transport pathways, and sinks of particulate trace elements in urban terrestrial environments to include the atmosphere, soils, and street and indoor dusts. Such studies reveal reductions in the emissions of some elements of historical concern such as $\mathrm{Pb}$, with interest consequently focusing on other toxic trace elements such as $\mathrm{As}, \mathrm{Cd}, \mathrm{Hg}, \mathrm{Zn}$, and $\mathrm{Cu}$. While establishment of levels of these elements is important in assessing the potential impacts of human society on the urban environment, it is also necessary to apply this knowledge in conjunction with information on the toxicity of those trace elements and the degree of exposure of human receptors to an assessment of whether such contamination represents a real risk to the city's inhabitants and therefore how this risk can be addressed.
\end{abstract}

S. Charlesworth

SUDS Applied Research Group, Coventry University,

Priory Street, Coventry CV1 5FB, UK

E. De Miguel

Environmental Geochemistry Group,

Madrid School of Mines, Rios Rosas 21,

28003 Madrid, Spain

A. Ordóñez $(\bowtie)$

Oviedo School of Mines, University of Oviedo,

Independencia 13, 33004 Oviedo, Spain

e-mail: aoalonso@uniovi.es
Keywords Urban geochemistry •

Urban solid deposits - Bioaccessibility .

Bioavailability · Risk assessment .

Urban geochemical cycles

\section{Introduction: urban particulates}

Urban geochemistry is a rapidly evolving science; it has to be since populations in cities continue to increase and their contribution to environmental contamination increases as a result (Pope et al. 2009; Wang et al. 2008; Charlesworth et al. 2003). The earliest studies were concerned with levels of trace elements in the solid materials that humans could be exposed to from atmospheric suspended particles, street dust, house dust, to soil. Identification and characterization of sources of these trace elements was carried out both qualitatively (which elements are associated with which sources) and quantitatively i.e., relative contributions of different emission sources to the total amount of a given element in a given urban material. With growing awareness of the potential health effects of particulate-associated pollutants, the focus widened to include problems of speciation, modes, and rates of transfer between different urban media, estimates of exposure through different routes such as inhalation, ingestion, dermal adsorption (Bowman et al. 2003), 
and potential impacts on human health, considering not only exposure to all types of sources for a particular pollutant across an urban area but also the proportion of population exposure attributable to different polluting sources (Zou et al. 2009).

The principal developments in urban geochemistry listed above have generally taken place first in investigations of $\mathrm{Pb}$ (because of its potential toxicity, widespread occurrence in urban particulate materials, and well-established main urban source, i.e., traffic), and since the now widespread introduction of unleaded fuels, have subsequently been applied to other trace elements. This paper therefore reviews the research carried out to elucidate sources, transport pathways, sinks, and impacts of particulate associated trace elements in the various spheres making up the urban environment.

\section{The urban aerosol}

Concern over the quality of urban air has driven the need for targets to improve emissions, which has lead to legislative controls (Williams 2004). These targets have been based on the sources of emissions, beginning in the UK, e.g., with the 1950s "London smogs", and concentrating mainly on smoke. However, suspended atmospheric particles can originate both naturally and from typically urban sources (i.e., vehicular traffic, domestic heating systems, etc.) therefore much research has attempted to differentiate natural from anthropogenic contributions. There is general agreement (cf. Van Dingenen et al. 2004) that the size of urban suspended particles follows a bimodal distribution, in which particulate matter of "natural" origin (resuspended soil and mineral particles) constitutes the coarsest fraction, while those associated with anthropic sources (combustion processes in most cases) are finer, generally $<2 \mu \mathrm{m}$. Investigations in different cities found that the dominant particle size lay in the sub-micron range (Lin and Lee 2004; Kasparian et al. 1998).

Studies ascertaining the particle size distribution and chemical composition of those emissions are important as such properties determine their potential health effects; i.e., that $<10 \mu \mathrm{m}\left(\mathrm{PM}_{10}\right)$ is considered "inhalable" (can reach the alveoli of the lungs and potentially cause irritation and disease), with the coarsest particles of this fraction becoming trapped in the nose, throat, and upper respiratory tract, while the $<2.5 \mu \mathrm{m}\left(\mathrm{PM}_{2.5}\right)$ fraction is regarded as "respirable", since they can penetrate deep into the respiratory system, generally beyond the body's natural clearance mechanisms, and are more likely to be retained and absorbed. The $\mathrm{PM}_{2.5}$ fraction is therefore associated with adverse health effects, such as asthma and even mortality (Kappos et al. 2004), as well as with ambient air quality problems, including visibility reduction (Horvath 2008; Lin and Tai 2001). While some researchers (e.g., Kappos et al. 2004) have reported difficulties in assessing the health effects of ultra-fine particles, i.e., those $<0.5 \mu \mathrm{m}$, research has mostly concentrated on the finest fraction. Trace elements found in association with these fine particulates and of toxicological concern include $\mathrm{As}, \mathrm{Cd}, \mathrm{Cr}, \mathrm{Hg}, \mathrm{Mn}, \mathrm{Ni}, \mathrm{Pb}$, and $\mathrm{V}$, exposure to which in occupational environments has been suspected of causing sinusitis, asthma and chronic bronchitis, pneumonia, lung hemorrhage, lung cancer, and brain hemorrhage (Choi et al. 2009; Crosby 1998).

The potential toxicity of such elements has encouraged much scientific research into their sources and levels in urban aerosols. Traffic has provided a primary focus, but emissions of suspended particles from other urban activities, such as fuel combustion for heating, industrial processes, etc., are also discussed in the following sections.

Traffic

The particle size distribution of exhaust emissions depends on driving patterns; freeway exhaust particles usually being approximately $0.1 \mu \mathrm{m}$, whereas urban driving generates coarser particles of up to $5 \mu \mathrm{m}$. In the past, vehicular sources have contributed large amounts of atmospheric lead due to the use of leaded petrol, ranging from $40 \%$ absolute $\mathrm{Pb}$ concentration (Kowalczyk et al. 1982) with little contribution from diesel traffic, to $4 \%$ when the contribution of diesel traffic is significant (due to the diluting effects of carbonaceous particles). The relative contribution of traffic to trace element loads has also been evaluated by $\mathrm{Ba} / \mathrm{Pb}, \mathrm{Br} / \mathrm{Pb}$ ratios (e.g., Sturges and Harrison 1986) wherein $\mathrm{Pb} / \mathrm{Br}$ ratios of between 0.8 and 4.7 are indicative of vehicular emissions and, using factor analysis, the scores on a factor that includes $\mathrm{Pb}, \mathrm{Cu}, \mathrm{Ba}$, and $\mathrm{Zn}$ (Viana et al. 
2006; De Miguel et al. 1999; Paterson et al. 1996). A recent modification to factor analysis, positive matrix factorization, has been used with multiple sources to give "significant information on anthropogenic sources" (Mazzei et al. 2008, p. 87). However, studies using radioactive isotope ratios (e.g., Chen et al. 2005) have enabled finer discrimination with Widory et al. (2004) using carbon isotopes to differentiate between diesel emissions and those of fuel oil, although they do admit that these conclusions are "subject to debate" (p. 959).

Catalytic converters were introduced in the mid1970s in the USA and mid-1980s in Europe, and with increasing use of multi-element analytical techniques such as ICP-AES, it was realized that platinum group elements (PGEs) or metals (PGMs) which included Pt, $\mathrm{Pd}, \mathrm{Rh}, \mathrm{Ru}$, Ir, and Os (Ravindra et al. 2004) had begun to accumulate in the environment. Barbante et al. (2001) estimated that up to 1.4 ton Pt year ${ }^{-1}$ could be released from vehicle catalytic converters globally and Schäfer et al. (1999) found that typical urban Pt deposition rates could reach $23 \mathrm{ng} \mathrm{m}^{-2}$ day $^{-1}$. These elements bioaccumulate (Palacios et al. 2000) and are also transported in the ultrafine, inhalable particle sizes, generally $<0.39 \mu \mathrm{m}$. A detailed review of PGE levels in environmental materials is beyond the scope of this paper, but Moldovan et al. $(2001,2002)$ and Ravindra et al. (2004), among others, have covered PGE mobility, bioaccumulation, and human health effects.

Domestic heating, coal, and oil combustion

The emissions profiles of coal and oil depend on their provenance, hence determining their contribution to the urban aerosol is difficult. Historically, coal combustion, for instance, has been one of the main sources of $\mathrm{Mn}, \mathrm{Cr}, \mathrm{Cu}, \mathrm{Co}, \mathrm{As}$, and $\mathrm{Se}$, but its exact emission profile depends on the type of coal burnt. Complicating the matter is the fact that its emission profile coincides to a great extent with that of soil resuspension, due to the similarity between the alumino-silicate matrix of soil particles and that of coal fly ash (Tomza 1984; Kowalczyk et al. 1982). Differentiating factors have been found due to the relative enrichment in $\mathrm{As}$ and $\mathrm{Se}$ and depletion in Mn of coal fly ash and the use of $\mathrm{Al}$, $\mathrm{Si}$, and $\mathrm{Ti}$ to trace the influence of coal combustion
(Han et al. 2010; Rose et al. 1994; Pacyna 1991; Kowalczyk et al. 1982). In most of Europe coal has mostly been replaced by natural gas as fuel for domestic heating with a consequent reduction in its contribution to the load of trace elements in urban environments.

Vanadium, and to a lesser extent $\mathrm{Ni}$ and $\mathrm{S}$, have been almost universally used as tracers of oil combustion (Sadiq and Mian 1994; Cornille et al. 1990; Boni et al. 1988; Kowalczyk et al. 1982), although Cornille et al. 1990, assigned up to $40 \%$ of all the $\mathrm{V}$ in the aerosol of an arid area to shale-like soil resuspension, thus highlighting the necessity to interpret data carefully, taking local conditions into account.

Resuspension of soil and street dust particles

Soil and street dust particles can be entrained by wind currents into the overlying air where they represent a significant proportion of its coarse fraction (Harrison et al. 1974). Although wind is clearly important, vehicular and pedestrian traffic (e.g., Patra et al. 2008; Kupiainen 2007), agricultural activities, street sweeping (Yuan et al. 2003) and construction operations can also contribute. Soil resuspension is probably the main source of $\mathrm{K}, \mathrm{Mg}$, and $\mathrm{Mn}$, and together with coal combustion, provides a significant amount of $\mathrm{Al}, \mathrm{Ca}, \mathrm{Ce}, \mathrm{Cr}, \mathrm{Fe}, \mathrm{La}, \mathrm{Sc}, \mathrm{Sr}$, Ti, and $\mathrm{Th}$ (Boni et al. 1988; Kowalczyk et al. 1982). Street dust and the fine soil fraction are enriched in anthropogenic trace elements and, if resuspended, can make a notable contribution to the inhalable trace element load of an urban aerosol. A study by Laidlaw and Filippelli (2008) found significant health risks to young people from resuspended soil contaminated with $\mathrm{Pb}$ both inside and outside the home, leading to blood lead levels (BLL) in children in excess of $10 \mu \mathrm{m} \mathrm{dl}^{-1}$ in some USA cities. In Cairo, Egypt, Sharaf et al. (2008) found BLLs up to $14.3 \mu \mathrm{m} \mathrm{dl}{ }^{-1}$ in children living by heavily trafficked roads, and asserted than the CDC (2007) $10 \mu \mathrm{m} \mathrm{dl}^{-1}$ advisory level is too high. However, soil particles contributing to the urban aerosol can originate naturally due to crustal erosion and the finest fraction of these "natural" particles can travel long distances, their chemical makeup reflecting the mineral composition of the original soil (Cornille et al. 1990). 
Other urban sources

Other sources include specific industrial processes, incineration, construction activities, road weathering, and maintenance, etc. The emission profile of refuse incineration depends on a number of process factors, but Pacyna (1983) and Kowalczyk et al. (1982) reported that incineration is a major source of $\mathrm{Zn}, \mathrm{Cd}$, and Sb. Wadge et al. (1986) found high levels of $\mathrm{Pb}$ and $\mathrm{Cd}$ in the finest fraction of refuse incineration flyash. For elements volatilized during combustion, an inverse relationship of concentration with particle size exists, due to the larger surface area-to-volume ratio of the smaller particles (Arditsoglou et al. 2004).

High levels of $\mathrm{Ca}$ can be related to the presence of cement dust, and hence to construction activities; the element has therefore been used as a tracer of suspended cement dust (Loredo et al. 2004; Gatz 1975). According to Kowalczyk et al. (1982), airborne cement particles should exhibit concentration ratios $\mathrm{K} / \mathrm{Ca} \approx 0.006$ and $\mathrm{Mg} / \mathrm{Ca} \approx 0.16$. Using $\mathrm{Ca}$ as an indicator of the presence of cement dust, Zhao et al. (2006) found that as well as soil and coal combustion, construction dust made up over $80 \%$ of the sources of resuspended dust and hence urban ambient $\mathrm{PM}_{10}$ in six cities in China.

In northern countries, the use of spiked tires in the cold season results in abrasion of the road surface, generating dust particles. Lastly, depending on the location of a city, sea spray may supply considerable amounts of $\mathrm{Na}$ to the atmosphere (Kowalczyk et al. 1982). Studies such as the one by Pryor et al. (2008) suggest that neglecting the interactions of sea spray in urban air quality considerations may lead to misleading conclusions being drawn.

\section{Source apportionment}

Source partitioning is a crucial element in the formulation and implementation of long-term strategies and environmental policies for reducing trace metal contamination and human exposure to potentially toxic trace metals (Duzgoren-Aydin 2007). The terms "source apportionment" and "receptor modeling" make use of various mathematical models to attempt to apportion the aerosol measured at a receptor site to its likely sources. The two most widely used are chemical mass balance $(\mathrm{CMB})$ and multivariate models. The latter employ multivariate analysis techniques to predict the number of relevant emission sources in the area and their individual contributions to a series of aerosol measurements (Harrison et al. 1997). These models, however, are not well suited for source apportionment when two or more emission sources in the study area have similar "signatures" or elemental emission profiles such as coal and soil as discussed above. Furthermore, an infinite number of models can be produced that will satisfy a given aerosol composition and all natural constraints which would be unhelpful (Henry 1987). In contrast, $\mathrm{CMB}$ models assume that the elemental composition of different source emissions is also known (not valid for all sites), so individual contributions of each source can be estimated by solving a system of linear equations (Cornille et al. 1990; Kowalczyk et al. 1982; Gatz 1975). However, this approach can be misleading because different elements may have different physicochemical fractionation processes, and thus their relative abundances may change significantly during transportation (Bollhofer and Rosman 2000). $\mathrm{Pb}$ isotope ratios as a fingerprint technique are beginning to be widely utilized in environmental studies, providing complementary information on the determination of sources of $\mathrm{Pb}$ and other sulphophile elements, such as $\mathrm{Hg}, \mathrm{As}$, $\mathrm{Sb}, \mathrm{Zn}$, and $\mathrm{Cu}$ (Zhu et al. 2001, 2003). The isotope ratios measured in environmental samples depend on the age of the ore bodies from which they are derived, as they are not affected by physical or chemical fractionation processes in the surface environment (Bollhofer and Rosman 2000; Zhu et al 2001). Pb isotope ratios have been used in numerous studies utilizing various types of urban samples, although this method of source apportionment can only be applied successfully if there is a significant difference between the isotopic composition of the target media and potential sources (Duzgoren-Aydin 2007).

Some studies have attempted to determine source etiology of metals in various environmental compartments using geographical information systems (GIS) mapping (Duzgoren-Aydin and Weiss 2008). The utilization of this tool allows large public health databases to be linked with large geospatial databases. This capability enables the analysis of relative information quickly to aid in the testing of hypotheses based on geographical patterns. Specific information (attributes) can be linked to location data, 
such as industrial or heavily trafficked areas (e.g., Dao et al. 2009). In addition, quantities and densities of people, industry, or heavy metals can be mapped and linked with other attributes such as blood lead values and lead concentrations in soil by population density or census tract. Similarly, areas of high and low concentration of metals can be objectively plotted.

Concentrations of elements found in soil are often compared against published guidelines such as Contaminated Land Exposure Assessment (CLEA), Soil Guideline Values (SGV) (Defra and EA 2002) or Trigger concentrations (ICRCL 1987). However, low sampling densities are sometimes utilized (e.g., Charlesworth et al. 2003 (one sample $0.4 \mathrm{~km}^{-2}$ ) and Lee et al. 2006 (five samples $\mathrm{km}^{-2}$ )) on which management decisions may be based where the significance of the concentration of a single sample is unknown. A knowledge of the spatial and temporal distribution of soil variability is fundamental to an understanding of urban processes and hence the implementation of suitable management strategies to mitigate any negative environmental impacts. A number of studies (Grzebisz et al. 2002; Lin et al. 2005; Navas and Machín 2002) have therefore focused on the spatial variability of soil characteristics using GIS to demonstrate that it varies with map scale, spatial location, and specific soil properties (Lin et al. 2005). In a nested soil sampling study in Milton Keynes, UK, which concentrated on so-called "hot spots" of elevated heavy metal concentration, Charlesworth (unpublished data) used ArcGIS 9.2 software to map sample variability at different scales. The largest scale took four samples $\mathrm{km}^{-2}$, the middle scale took 11 samples $\mathrm{km}^{-2}$, and at the smallest scale, 32 samples $\mathrm{km}^{-2}$ were taken (see Fig. 1). Results (Table 1) underscore the influence of sampling scale on the ability to detect hot spots and to determine their spatial boundaries, indicated by the variability of concentrations within the sampling unit, in a highly heterogeneous medium as urban soil.

Depending on its physical characteristics and climate conditions, airborne particulate material may settle onto a surface of some kind in the urban area. The next sections follow these particles onto the street and thence indoors, assessing their eventual risk to the environment as a whole and to those who live in it in particular.

\section{Street dust}

Solid particles that accumulate on outdoor, impervious materials are collectively referred to as "street dust", while particles found inside urban dwellings are commonly termed "house or indoor dust", suggesting that all this material is inhalable. However, studies of various urban environments (e.g., Sansalone et al. 1998) have found that the majority of urban sediments are $>400 \mu \mathrm{m}$ by mass, and therefore the term "dust" may be inappropriate. However, it is a term in general use to describe such material and so will be used here.

Street dust does not remain deposited for long; a study by Allott et al. (1990) in northwest England, using ${ }^{137} \mathrm{Cs}$, found that the half-life of street dust was between 190 and 370 days. It is easily resuspended back into the atmosphere, where it contributes a significant amount of trace elements (Zhao et al. 2006), or precipitation washes it out where it can become an important component of suspended and dissolved solids in street run-off (Vermette et al. 1991), so the temporal variability of street dust trace element concentration is high, and most studies do not monitor long enough in order to evaluate it. Street dust also presents a pronounced small-scale heterogeneity (Leharne et al. 1992), reflecting the mobility and rapid environmental alteration of street dust and also the variable distribution of its urban sources.

There are several point-sources that contribute directly to street dust (Hopke et al. 1980; Schwar et al. 1988) the most relevant of which is vehicular traffic (see Sect. "Traffic"), in particular car exhaust emissions which were responsible for elevated concentrations of $\mathrm{Pb}, \mathrm{Zn}, \mathrm{Cd}, \mathrm{Cu}$, and $\mathrm{Ba}$. The gradual shift from leaded to unleaded petrol has reduced the input of $\mathrm{Pb}$; it was found by Charlesworth et al. (2003) that $\mathrm{Pb}$ concentrations in street dusts from Birmingham, UK, had declined over a nearly 30 -year period from an average of $1,300 \mu \mathrm{g} \mathrm{g}^{-1}$ in residential streets (Davies et al. 1987) to $48 \mu \mathrm{g} \mathrm{g}^{-1}$. Therefore, some countries have now dropped $\mathrm{Pb}$ from their atmospheric monitoring programs, concentrating instead on $\mathrm{Zn}$ and $\mathrm{Cu}$ (Foster and Charlesworth 1996), with the suggestion being made by Wong et al. (2006) that an inventory of their isotopic signatures be made, similar to that for $\mathrm{Pb}$ in order to assist in identifying and eventually quantifying their sources. High concentrations of $\mathrm{Zn}$ and $\mathrm{Cd}$ have been traditionally related to 
Fig. 1 A Comparison of the spatial distribution of $\mathrm{Zn}$ $\left(\mu \mathrm{g} \mathrm{g}^{-1}\right)$ in soil at different scales, Milton Keynes, UK. $A=4$ samples $\mathrm{km}^{-2}$; $B=11$ samples $\mathrm{km}^{-2}$; $C=32$ samples $\mathrm{km}^{-2}$ (Digimap 2008)

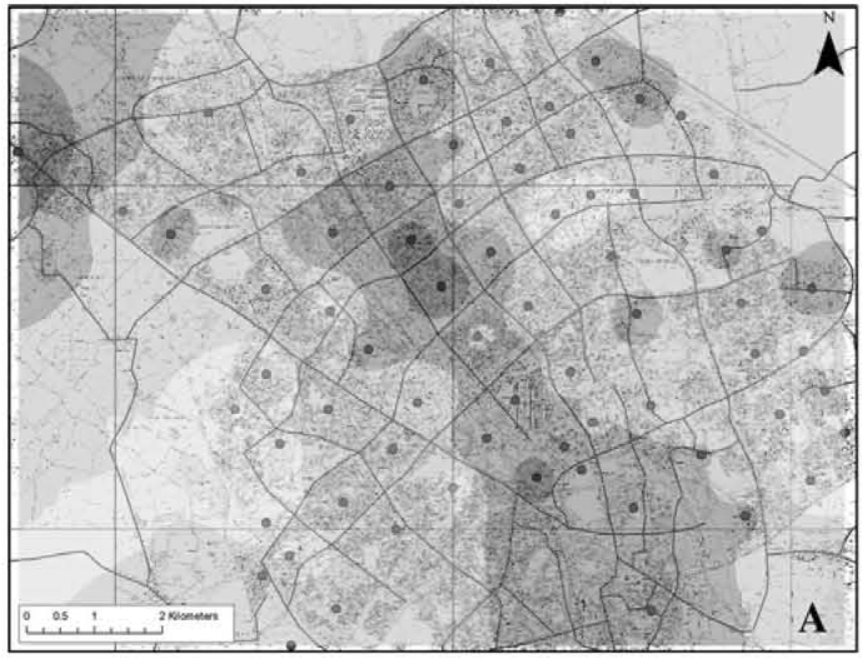

\section{Legend \\ Zn mg / kg}

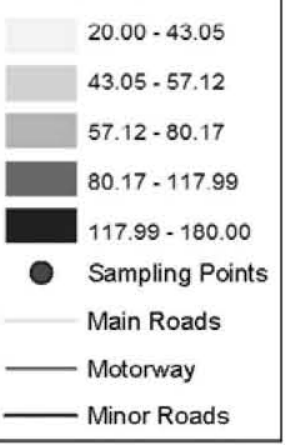

A

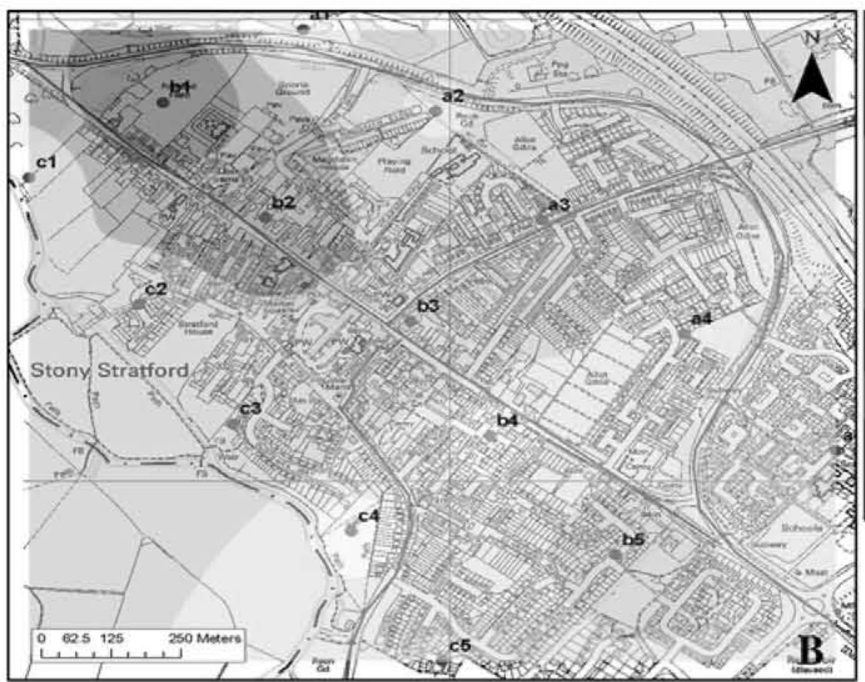

\section{Legend}

\section{Zn mg / kg}

$79.85 \cdot 96.23$

$96.23-126.97$

$126.97-184.67$

$184.67-292.96$

292.96 - 496.21

- Sample Points Main Road

Minor Road

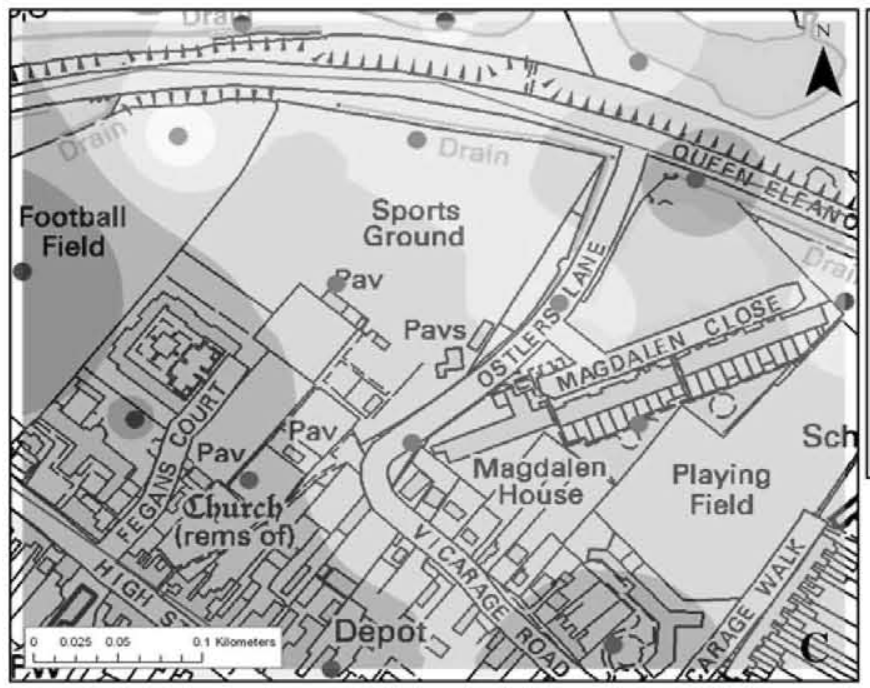

Legend

Zn mg / kg

$79.22 \cdot 98.04$ $98.04-131.81$

$131.81 \cdot 102.40$

$192.40-301.12$

$301.12 \cdot 496.21$

Sampling Points Road 
Table 1 Mean metal concentrations $\left(\mu \mathrm{g} \mathrm{g}^{-1}\right.$ ) from a nested soil sampling study, Milton Keynes, England

\begin{tabular}{|c|c|c|c|c|c|}
\hline & $\mathrm{Pb}$ & $\mathrm{Zn}$ & $\mathrm{Ni}$ & $\mathrm{Cu}$ & $\mathrm{Cd}$ \\
\hline \multicolumn{6}{|c|}{$\mathrm{S} 1(n=70)$} \\
\hline Mean & 51.1 & 74.57 & 17.91 & 20.5 & 0.51 \\
\hline SD & 127.1 & 30.04 & 3.52 & 9.71 & 0.55 \\
\hline \multicolumn{6}{|c|}{$\mathrm{S} 2(n=15)$} \\
\hline Mean & 184.6 & 155.3 & 14.75 & 50.69 & 0.67 \\
\hline SD & 263.0 & 101.7 & 5.07 & 37.8 & 0.47 \\
\hline \multicolumn{6}{|c|}{$\mathrm{S} 3(n=16)$} \\
\hline Mean & 235.6 & 178.7 & 18.72 & 48.61 & 0.68 \\
\hline SD & 227.7 & 104.8 & 4.31 & 30.44 & 0.39 \\
\hline
\end{tabular}

tire wear (Stigliani and Anderberg 1991; Fergusson and Kim 1991) but Zn compounds are also used as antioxidants and as detergent/dispersant improvers in lubricating oils (Begum et al. 2007; Drew 1975), contributing to the influence of traffic on the $\mathrm{Zn}$ load in street dust. Like $\mathrm{Zn}$, Ba dispersions are widely used as detergents/dispersants but also as oxidation and corrosion inhibitors in lubricating oils for diesel and other combustion engines, and as smoke suppressant additives in diesel fuels, explaining the high Ba concentrations in street dust (Kowalczyk et al. 1982). Oxidation of lubricating oils upon exposure to air at high temperatures results in the formation of organic acids, alcohols, ketones, aldehydes, and other organic compounds that are corrosive to metal. This corrosive action results in the release of $\mathrm{Zn}, \mathrm{Cu}$, and Cd-bearing alloys (Drew 1975) or, as in the case of sinterized materials used in the automobiles' oil pump, of $\mathrm{Ni}, \mathrm{Cu}$, and Mo to the urban environment and their accumulation in street dust (De Miguel et al. 1997).

Although particles emitted directly from combustion engines usually lie in the range $<1 \mu \mathrm{m}$ under normal driving conditions, stop-and-go activities and acceleration-deceleration cause resuspension and emission of larger particles (Kim et al. 1998). Also, fine atmospheric and street dust particles undergo an intense process of condensation growth and agglomeration that results in aggregates of larger size, as revealed by electronic microscopy (Dongarrà et al. 2003). This increase in particle size is the reason why a large percentage of trace elements emitted from automobile exhausts do not travel far, but are deposited close to the road, street, or motorway where they originated (Warren and Birch 1987).
Another localized source of trace elements in street dust is the weathering, construction, renovation, and redecoration of buildings and building materials. Corrosion of galvanized-metal structures (roofs, balconies, window ledges, crash barriers, etc.) contributes large amounts of $\mathrm{Zn}$ and $\mathrm{Cd}$ to street dust (Fergusson and Kim 1991). This process can raise the concentration of both elements in street dust to values of $44,000 \mu \mathrm{g} \mathrm{g}^{-1}$ of $\mathrm{Zn}$ and $20 \mu \mathrm{g} \mathrm{g}^{-1}$ of $\mathrm{Cd}$ in the particulate material collected from under the metal ledges and balconies of old buildings (De Miguel et al. 1997). Elevated levels of $\mathrm{Cd}$ and $\mathrm{Pb}$ in street dust can also be associated with the accumulation of paint flakes from deteriorating old facades or recently redecorated walls (Rundle and Duggan 1986; Davies et al. 1987; Schwar et al. 1988; Fergusson and Kim 1991). The interest in this source of $\mathrm{Pb}$ in street dust arose from evidence that children were readily exposed to these particles, both at home and at school (Duggan et al. 1985), and that this exposure resulted in toxic effects (Harvey et al. 1985; Mielke et al. 1999). Possibly also associated with pulses of construction activity, relatively high activities of radioactive nuclides have been found in some urban dusts in Coventry, UK (Charlesworth and Foster 2005) where some samples approached (and even exceeded) the ICRP (1991) guidelines of $1 \mathrm{mSv}$ year ${ }^{-1}$ for members of the public. Average heavy metal concentrations in the street dust of some cities are shown in Table 2.

Some of this outdoor dust and its associated pollutants eventually makes its way into the interior of buildings where studies of such contamination 
Table 2 A comparison of the mean (or range of) concentrations of heavy metals in street dusts and urban soils found in studies globally $\left(\mu \mathrm{g} \mathrm{g}^{-1}\right)$

\begin{tabular}{|c|c|c|c|c|c|c|c|c|}
\hline City & Population $\left(\times 10^{3}\right.$ hab) & & References $^{\mathrm{a}}$ & $\mathrm{Cd}$ & $\mathrm{Cu}$ & $\mathrm{Ni}$ & $\mathrm{Pb}$ & $\mathrm{Zn}$ \\
\hline New York (USA) & 18,200 & Str. dust & 1 & 8 & 355 & NA & 2,583 & 1,811 \\
\hline Seoul (Korea) & 10,400 & Str. dust & 2 & 3 & 101 & NA & 245 & 296 \\
\hline Bangkok (Thailand) & 9,100 & Soil & 3 & 0.3 & 42 & 25 & 48 & 118 \\
\hline Mexico City (Mexico) & 8,800 & Soil & 4 & NA & 101 & 40 & 141 & 307 \\
\hline \multirow[t]{2}{*}{ London (UK) } & 7,500 & Str. dust & 5 & 2.7 & 108 & NA & 2,100 & 539 \\
\hline & & Soil & 6 & NA & 73 & NA & 294 & 183 \\
\hline \multirow[t]{2}{*}{ Hong Kong (China) } & 7,000 & Str. dust & 7 & NA & $92-392$ & NA & $208-755$ & $574-2,397$ \\
\hline & & Soil & 8 & NA & 25 & NA & 93 & 94 \\
\hline Berlin (Germany) & 3,400 & Soil & 9 & 0,7 & 54 & 10 & 133 & 223 \\
\hline \multirow[t]{2}{*}{ Madrid (Spain) } & 3,200 & Str. dust & 10 & NA & 188 & 44 & 193 & 476 \\
\hline & & Soil & 11 & NA & 72 & 14 & 161 & 210 \\
\hline Amman (Jordan) & 1,900 & Str. dust & 12 & $2.5-3.4$ & $69-117$ & $27-33$ & $219-373$ & NA \\
\hline Hamburg (Germany) & 1,800 & Soil & 13 & 2.0 & 147 & 63 & 168 & 516 \\
\hline Taejon (Korea) & 1,600 & Str. dust & 14 & NA & $47-57$ & NA & $52-60$ & $172-214$ \\
\hline Damascus (Syria) & 1,400 & Soil & 15 & NA & 34 & 39 & 17 & 103 \\
\hline Naples (Italy) & 1,000 & Soil & 16 & NA & 74 & NA & 262 & 251 \\
\hline \multirow[t]{2}{*}{ Birmingham (UK) } & 1,000 & Str. dust & 17 & 1.6 & 467 & 41 & 48 & 534 \\
\hline & & Soil & 18 & 0.9 & 147 & 34.5 & 160 & 320 \\
\hline Seville (Spain) & 700 & Soil & 19 & NA & 68 & 22 & 137 & 145 \\
\hline Palermo (Italy) & 660 & Soil & 20 & NA & 63 & 18 & 202 & 138 \\
\hline \multirow[t]{2}{*}{ Oslo (Norway) } & 630 & Str. dust & 10 & 1.4 & 123 & 41 & 180 & 412 \\
\hline & & Soil & 21 & 0.4 & 32 & 28 & 56 & 160 \\
\hline Hamilton (Canada) & 500 & Str. dust & 22 & 4 & 129 & NA & 214 & 645 \\
\hline Tallinn (Estonia) & 400 & Soil & 23 & NA & 45 & 16 & 75 & 156 \\
\hline Christchurch (New Zealand) & 370 & Str. dust & 1 & 1 & 137 & NA & 1,090 & 548 \\
\hline Cincinnati (USA) & 330 & Str. dust & 24 & NA & 253 & NA & 650 & NA \\
\hline \multirow[t]{2}{*}{ Coventry (UK) } & 300 & Str. dust & 17 & 0.9 & 226 & 130 & 47 & 386 \\
\hline & & Soil & $(*)$ & 1.6 & 65.8 & 26.6 & 14.6 & 224.5 \\
\hline Lancaster (USA) & 140 & Str. dust & 5 & 3.7 & 75 & NA & 1,090 & 260 \\
\hline \multirow[t]{2}{*}{ Avilés (Spain) } & 80 & Str. dust & 25 & 22 & 183 & 28 & 514 & 4,892 \\
\hline & & Soil & 25 & 2.2 & 63 & 17 & 149 & 376 \\
\hline Urbana (USA) & 40 & Str. dust & 26 & 1.6 & NA & 250 & 1,000 & 320 \\
\hline \multirow[t]{2}{*}{ Mieres (Spain) } & 25 & Str. dust & 27 & 1.6 & 112 & 26 & 318 & 420 \\
\hline & & Soil & 27 & 1.0 & 57 & 34 & 92 & 233 \\
\hline
\end{tabular}

a (1) Fergusson and Ryan (1984), (2) Chon et al. (1995), (3) Wilcke et al. (1998), (4) Morton-Bermea et al. (2008), (5) Harrison et al. (1981), (6) Thornton 1991), (7) Wang et al. (1998), (8) Li et al. (2001), (9) Birke and Rauch 2000), (10) De Miguel et al. (1997), (11) De Miguel et al. (1998), (12) Jiries et al 2001), (13) Lux 1986), (14) Kim et al. (1998), (15) Möller et al. (2005), (16) Imperato et al. (2003), (17) Charlesworth et al. (2003), (18) Shepherd et al. (2006), (19) Madrid et al. (2002), (20) Manta et al. (2002), (21) Tijhuis et al. (2002, (22) Droppo et al. (1998), (23) Bityukova et al. (2000), (24) Tong 1998), (25) Ordóñez et al. (2003), (26) Hopke et al. (1980), (27) Loredo et al. (2004), (*) new data

have found levels of metals and other toxic chemicals of concern. The following sections consider this indoor dust, and also one of the main sources of this and street dust, urban soil.

\section{Indoor dust}

The main sources of indoor house dust include soil and street dust particles; these are carried indoors 
adhered to clothes and shoes, swept indoors by wind drafts, or even brought inside on the fur of domestic animals (Tong 1998). In the case specifically of $\mathrm{Pb}$, it is well documented that exterior lead sources are major contributing sources of interior (indoor) lead contamination due to the trans-location of particulates (Lanphear et al. 1998; Wong et al. 2000; Farfel et al. 2003). The relative contribution of the urban aerosol and of indoor sources of trace elements (cooking and other combustion processes, rubber, wall paint, fabrics, pigments) has yet to be conclusively evaluated (Hogervorst et al. 2007; Edwards et al. 1998; Fergusson and Kim 1991). As in the case of street dust, concern over inhalation, ingestion, and dermal exposure to house dust has fueled research, since it has been cited as one of the major sources of exposure to pesticides and metals, particularly $\mathrm{Pb}$, in children (Edwards et al. 1998). In fact, lead-based paint is often the prime suspect as the source when a child presents with elevated blood lead (CDC 2007). Turner and Simmonds (2006) reported that, in common with many other studies worldwide, enrichment of $\mathrm{Cd}, \mathrm{Cu}, \mathrm{Pb}, \mathrm{Sn}$, and $\mathrm{Zn}$ in dusts from four regions across the UK were of concern. However, Tong and Lam (2000) found that activities such as floor sweeping and dusting reduced the levels of metals in houses in Hong Kong. Chattopadhyay et al. (2003) found that, while atmospheric concentrations of $\mathrm{Pb}$ have reduced since the introduction of unleaded petrol (see Sect. "The urban aerosol"), that of household dusts in Sydney, Australia, have remained essentially unchanged, due not only to the accumulation of $\mathrm{Pb}$ inside the house from the use of old leaded paints (the prevalence of lead-based paint hazards increases with the age of housing), but also the historical accumulation of more than 80 years of leaded petrol deposition in the urban area, in addition to any other exterior sources. Furthermore, recent studies (Sutherland et al. 2002; Duzgoren-Aydin 2007) have emphasized that re-suspended lead-bearing particulates deposited from past anthropogenic activities are still an important source of prevailing lead pollution in the surface environment. However, given the ubiquitous and complex nature of environmental lead, assigning an attributable risk to any one lead source and then estimating the extent of contribution of each potential source(s) of lead, for instance, to elevated blood lead in a child is difficult and arduous.
As mentioned before, one of the vectors for the transport of contaminants indoors is soil, and it has been found that soil can act as a repository for historical contamination not only due to traffic but also industry (e.g., Charlesworth et al. 2003). The following section therefore considers levels and sources of soil contamination in urban areas.

\section{Urban soil}

The term urban soil can be understood to encompass all types of non-paved land within the city limits: public and private green areas (parks and gardens), undeveloped land, building lots, etc. Whereas the characterization of street dust offers an instantaneous "snapshot" of an urban environment's condition, urban soil rather acts as a pollutant sink and, if undisturbed, preserves the cumulative history of trace elements inputs into it (although not in the orderly, sequential fashion of an urban lake sediment).

Soil particles do not necessarily remain undisturbed, but can become part of street dust or even of the urban aerosol. Particles smaller than $100 \mu \mathrm{m}$ move in "suspension" and the finest among them may remain airborne for prolonged periods of time. The process of suspension is all the more intense if the small particles are accompanied by particles moving by "saltation", which upon landing back on the surface will help to entrain the finest material (Nicholson 1988). Consequently, exposure to trace elements in urban soil does not occur solely by ingestion or dermal contact but also through inhalation of resuspended soil particles. However, the most immediate route of exposure for children, the most sensitive segment of the population, is hand-tomouth activity during games and the habit of "pica", i.e., mouthing of non-food objects, with several investigations suggesting that urban soil and dirt represent a significant intake of trace elements for children living in urban areas (Abrahams 2002; Watt et al. 1993; Rundle et al. 1985).

Although generally lower than those found in street dust, urban soil can contain enriched levels of trace elements relative to natural background levels (e.g., Biasioli et al. 2007; Charlesworth et al. 2003; Charlesworth and Foster 2005). Table 2 shows heavy metal concentrations in soils from various cities of the world. The main sources of these trace elements include the 
atmospheric deposition of particles generated by automotive traffic, heating systems, and resuspended street dust, the uncontrolled disposal of urban and commercial wastes, and the addition of fertilizers and composted sewage sludge to the soil (Shi et al. 2008; Yesilonis et al. 2008; De Miguel et al. 1998).

The exact contribution of each single source to the load of trace elements in urban soils, including the natural parent material, is difficult to quantify (Norra et al. 2006), since all the various inputs are integrated in the soil over time, and urban soils are periodically disturbed by landscaping, construction, irrigation, and partial or total replacement, to name a few. The influence of atmospheric deposition is fairly uniform across the city and gives rise to "urban background" levels of trace elements, which are higher than those in natural soils. For example, De Miguel et al. (1998) cite enrichment factors of 2.3, 2.6, and 4.0 for $\mathrm{Zn}, \mathrm{Cu}$, and $\mathrm{Pb}$, respectively, in the urban soil of Madrid relative to natural background levels. If the atmospheric aerosol has received contributions from industrial sources, the increase in trace element soil concentrations relative to natural levels is much more pronounced. Ordóñez et al. (2003) found concentrations of $\mathrm{Zn}$ and $\mathrm{Cd}$ as high as 2,000 and $8 \mu \mathrm{g} \mathrm{g}^{-1}$, respectively, downwind from a $\mathrm{Zn}$ smelter in Avilés city (see Table 2). Moreover, the influence of atmospheric deposition is not restricted to soils within the city limits. The effect of atmospheric fallout from the city of Madrid is significant in soils up to a distance of $15 \mathrm{~km}$ from the city center for $\mathrm{Pb}, \mathrm{Cu}$, and $\mathrm{Zn}$ (Fig 2) decreasing abruptly or disappearing totally beyond that distance (Llamas et al. 1993). Charlesworth et al. (2007) plotted the distribution of $\mathrm{Zn}, \mathrm{Ni}, \mathrm{Cu}, \mathrm{Cd}$, and $\mathrm{Pb}$ across the City of Coventry, UK, and found "hot spots" associated with the heavily trafficked main roads and industrial areas, but these elevated concentrations also reduced considerably at the city limits.

Unlike the influence of atmospheric deposition, the disposal of urban and commercial wastes, and the addition of fertilizers and composted sewage sludge have a very localized effect on the trace element content of urban soils. If present, however, these sources can contribute a larger amount of a number of trace elements to the urban soil than atmospheric deposition does. De Miguel et al. (1998) found that urban soils amended with composted sewage sludge presented levels of $\mathrm{Cu}, \mathrm{Ni}, \mathrm{Pb}$, and $\mathrm{Zn}$ that were 2-3 times higher than those in urban soils which did not

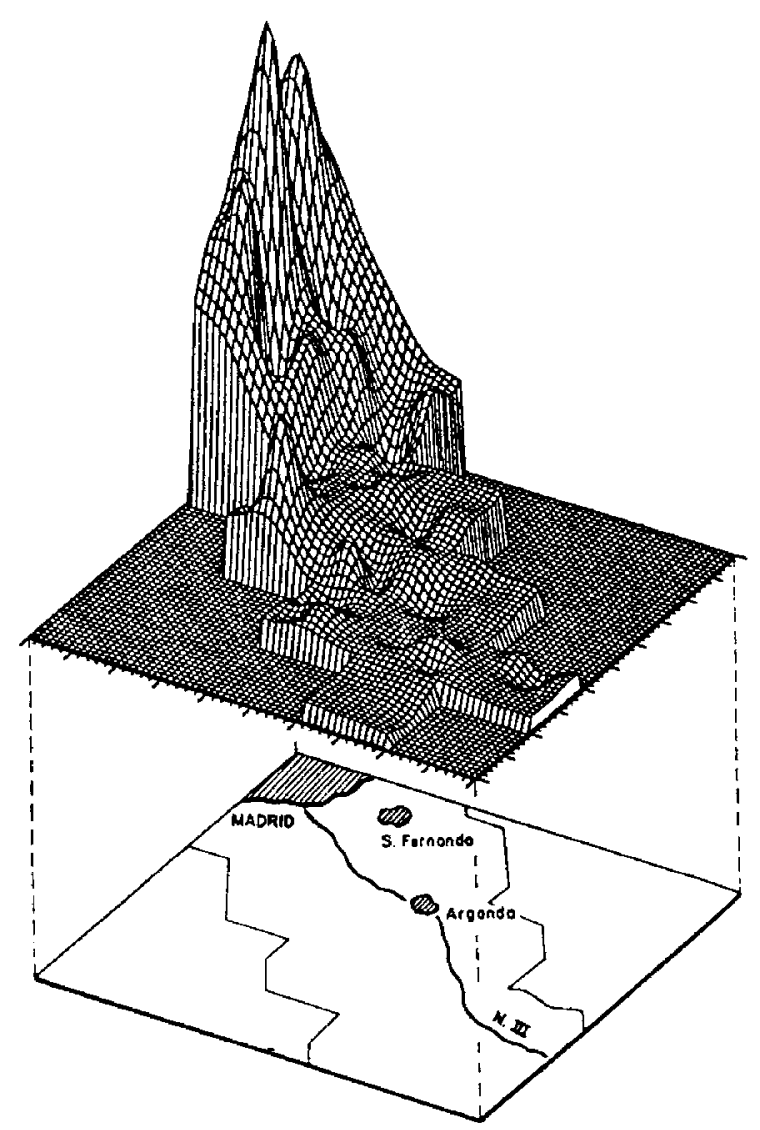

Fig. 2 The distribution of soil lead concentrations $\left(\mu \mathrm{g} \mathrm{g}^{-1}\right)$ in and around Madrid

receive compost additions. As a consequence, the highest levels of metals in soil were detected in some of the best-kept parks and gardens in the city, where fertilizing takes place on a regular basis. Concern over the potential implications of sewage sludge application, in terms of increased trace element load in soil, has fueled scientific research and legislative action in this field (Berti and Jacobs 1998; Giusquiani et al. 1992).

Urban soil does not only act as a net accumulator of trace elements but also acts as a significant source to the atmospheric aerosol and, particularly, to street dust. An example of this role is provided by De Miguel et al. (1997), who found that some of the highest concentrations of $\mathrm{Pb}$ in the street dust of Oslo were not associated with dense traffic but with nearby soils where $\mathrm{Pb}$ had accumulated over long periods of time from a $\mathrm{Pb}$ smelter that was shut down several years before the street dust sampling campaign took place. 
Some of the sources of trace elements in street dust and soil have been established in these sections, the fact that they can become entrained and transported in the atmosphere and that hazardous contaminants can be stored in various urban environmental compartments. The following section considers whether their presence constitutes a risk to the environment as a whole, or arguably more importantly, whether they constitute a risk to human health. This involves a consideration of how urban geochemistry can be modified to take account of whether pollutants are bioavailable or bioaccessible, and the ways in which potential risk can be estimated.

\section{Risk and health implications}

One of the major research interests in the field of urban geochemistry concerns the potentially adverse health effects of exposure to urban pollutants. Until recently, most studies had either established an inferred link between elevated concentrations of toxic elements in street dust and soil and the observed incidence of a given effect in a population, or had directly equated risk with predominance of mobile chemical species, as determined in sequential (Tessier et al. 1979) or selective extraction protocols (Banerjee 2003). The ecotoxicological significance of trace elements in street dust had also been directly evaluated by means of bioassays (Wang et al. 1998). In the last few years, risk-assessment strategies-extensively employed by regulatory authorities to define soil screening levels or soil guideline values-have increasingly been adopted and, when necessary, adapted to the peculiarities of urban environments in order to appraise the relevance-in terms of health effects - of toxic elements and compounds in urban matrices by jointly considering toxicity of the contaminants and level of exposure of the population (De Miguel et al. 2007; Ferreira-Baptista and De Miguel 2005; Lee et al. 2005; Kim et al. 2005; Hemond and Solo-Gabriele 2004; Granero and Domingo 2002; Wcislo et al. 2002; Boyd et al. 1999).

Toxicity values for carcinogens (slope factors) and non-carcinogens (reference doses), which are constantly being reviewed, are expressed as point estimates with an indication of the uncertainty associated with their determination, usually spanning one order of magnitude. These toxicity values are usually taken for granted by risk assessors, resulting in that risk assessment is essentially the assessment of the degree of exposure, measured as a chronic or life-time average daily dose (in milligrams of contaminant per unit of body weight and unit of time). The dose received through ingestion, inhalation and dermal absorption of trace elements in urban particulate materials depends on four types of variables: contact rate, exposure frequency, exposure duration, and body weight of the potentially exposed population, the estimates of which are again affected by a variable degree of uncertainty. This uncertainty and the fact that these variables are all population-specific greatly complicate the task of determining the exact contribution of each exposure medium to the overall risk experienced by the exposed individual. The aforementioned uncertainties notwithstanding, risk assessment has proven to be a very useful tool to reveal the true implications for human health of the concentrations of trace elements found in urban media.

Preliminary steps in the risk-assessment process include whether elements associated with the solid deposit of interest exceeds published or site-specific background values, or those limits set by national agencies (Sastre et al. 2002). In order to facilitate this analysis, especially when utilizing spectrometric techniques, digestion of the material is required in order to liberate the elements of interest. There are a number of well-established digestion protocols (USEPA 1994, 1996, 1997; Tam and Yao 1999; Linge 2008), however there is no universal method applicable for all elements and analytical equipment used, due to the complex nature of environmental samples and the availability and technical limitations of analytical equipment (Duzgoren-Aydin et al. 2010). The standard practice of pseudo-total digestion of samples using aqua regia or similar "strong" digestion protocols may lead to an overestimate of risk since only a portion of the elements released in this way would ever be absorbed by the human body. As a result, many digestion protocols have been developed that attempt to mimic conditions, whereby metals can be assimilated into living organisms. The following sections consider some of those techniques.

\section{Speciation}

Determination of particulate-associated element concentrations is an important initial step for the 
assessment of origin, relative mobility, and fate of contaminants (Duzgoren-Aydin et al. 2010). Based on the protocol developed by Tessier et al. (1979), the speciation of urban deposits has elicited much study, showing that street and house dust do agree fairly well regarding general trends in trace-element partitioning. It has been found that $\mathrm{Pb}$ and $\mathrm{Zn}$ are preferentially associated with the carbonate and $\mathrm{Fe}$ $\mathrm{Mn}$ oxide fractions, and $\mathrm{Pb}$ to a lesser extent with the exchangeable fraction; $\mathrm{Cu}$ is predominantly bound to the organic fraction; and $\mathrm{Cd}$ is associated with the first two fractions and shows the highest affinity of all these elements for the exchangeable fraction (Charlesworth and Lees 1999; Wang et al. 1998; Evans et al. 1992). According to these results, the mobility of trace elements in street dust follows the sequence: $\mathrm{Cd}>\mathrm{Pb} / \mathrm{Zn}>\mathrm{Cu}$, and concern about their environmental implications should, perhaps, observe the same order. The carbonate fraction is less important in urban soils and the relevance of the $\mathrm{Fe}-\mathrm{Mn}$ oxides, organic matter, and residual fraction increases (Serrano-Belles and Leharne 1997; Evans et al. 1992). This fact probably arises from a number of causes, among them the lower abundance of calcite, the lower $\mathrm{pH}$, and higher concentration of organic matter in urban soil relative to street dust. Trace elements are consequently more tightly bound to soil than to street dust particles, a fact that corroborates the role of urban soil as a sink for pollutants. However, changes in the environmental conditions of the soil $(\mathrm{pH}$, redox potential) might result in the release of part of the load of trace elements that have accumulated over time. However, there are many sequential digestion protocols and little consensus regarding which method is the most appropriate to use (Perez-Santana et al. 2007). The cold extraction method as detailed in Sutherland 2002 particularly appears to be relatively cost- and timeeffective as well as an environmentally sound screening procedure for monitoring programs involving numerous samples from diverse settings. However, results of this method should be accompanied with total element concentrations, as the proportion of the element able to be extracted may vary significantly with its origin as well as the type of sample (Duzgoren-Aydin et al. 2010). It is also felt that elucidating the binding sites on particulates does not give the kind of information required when assessing impacts on human health.

\section{Bioaccessibility and bioavailability}

Bioaccessibility is normally defined as the fraction of the trace element content that is available in the gastrointestinal tract for transport across the intestinal lumen, whereas the term bioavailability usually denotes the ingested contaminant fraction that actually reaches the systemic circulation (not all the mass of metal released during its transit in the gastrointestinal tract will be absorbed). The toxicity values used in risk assessments for ingestion are expressed in terms of absorbed doses and are often derived from assays that employ soluble salts or other easily available chemical forms of trace elements. Consequently, human health-risk assessments implicitly assume that the concentration term used in standard equations to quantify exposure represents the amount of trace elements in the sample that are available for absorption (i.e., bioavailable) in the gastrointestinal tract. In vivo assays have been carried out to evaluate bioavailability but they are expensive and complicated. They can be substituted, without great loss of accuracy, by in vitro tests (RIVN 2006) that simulate the biochemical environment, temperature, and duration of the various stages of ingestion (Oomen et al. 2002). Although undoubtedly easier to control than in vivo assays, in vitro experiments commonly produce uncertain and little reproducible results due to, among other difficulties, the very large number and instability of reactants and solutions, and the fact that concentrations in chyme can be near or below quantification limits.

Probably as a consequence, most in vitro studies of urban particulate materials have focused on the bioaccessibility of trace elements in soil and dust, operationally defined as the maximum amount of metal that is soluble in a synthetic gastric fluid (Hamel et al. 1998). A majority of these studies have used hydrochloric acid (adjusted to $\mathrm{pH}=1.5$ ) as a surrogate for gastric juice, as in the European Standard Toy Safety Protocol EN-71 (European Committee for Standardization 1995; Rasmussen et al. 2008) and some have extracted trace elements in the sample with glycine, again adjusted to $\mathrm{pH}=1.5$ with conc. $\mathrm{HCl}$ (Ruby et al. 1999; Madrid et al. 2008). The variability in the, sometimes contradictory, results arrived at by different researchers reflect the many and complex factors that influence how much of the total trace element load 
in a sample is bioavailable (element investigated, granulometry and mineralogy of the sample, organic carbon content, mode of retention, anthropogenic or natural origin, acid-to-sample ratio, etc.). Madrid et al. (2008) report bioaccessibility values (relative to an aqua regia extract) of up to $86 \%$ for $\mathrm{Ni}$ and $83 \%$ for $\mathrm{Zn}$, and as low as $1 \%$ for $\mathrm{Cr}$ in the $<2 \mu \mathrm{m}$ fraction of soils from two different urban environments, and an order of bioaccessibility $\mathrm{Ni}=\mathrm{Zn}>\mathrm{Pb}>$ $\mathrm{Cu}>\mathrm{Cr}$ for Seville and $\mathrm{Pb}=\mathrm{Cu}=\mathrm{Zn}>\mathrm{Ni}>\mathrm{Cr}$ in Torino. Rasmussen et al. (2008) analyzed the $\mathrm{HNO}_{3}+\mathrm{H}_{2} \mathrm{O}_{2}$ "total" and $\mathrm{HCl}$ bioaccessible contents of the $<150 \mu \mathrm{m}$ fraction of samples from urban gardens and indoor dust in Ottawa, producing an order of bioaccessibility of $\mathrm{Cu}=\mathrm{Zn}>\mathrm{Ni}$ for soil, and $\mathrm{Zn}>\mathrm{Cu}=\mathrm{Ni}$ for dust. Moreover, not only were concentrations of metals in indoor dust higher than in outdoor soil, but also their bioaccessibility was determined to be 1.5-2.5 times higher (i.e. $44 \%$ for $\mathrm{Cu}$ and $\mathrm{Ni}$ and $65 \%$ for $\mathrm{Zn}$ ). Most studies of metal bioavailability in soils have been conducted in locations strongly affected by industrial or mining operations (Schroder et al. 2003; Ruby et al. 1996). One of the few studies on uncontaminated urban soils was carried out by Ljung et al. (2007) in Uppsala (Sweden), where the upper $10 \mathrm{~cm}$ of playground soil was aqua-regia digested and bioavailability assessed after Oomen et al. (2003). Bioavailability followed the order: $\mathrm{Cd}(26 \%)>\mathrm{As}(16 \%)>\mathrm{Pb}=\mathrm{Cr}=\mathrm{Ni}$ (4\%) for the $<50 \mu \mathrm{m}$ fraction, considered to represent the particulate material that children ingest accidentally while playing.

Attempting to determine the relevance of, and hence give a context to, urban environmental levels of potentially toxic elements has added further complicating layers to what was already a complex situation. Concentrations of metals in the neutral-pH intestinal phase have been found to be lower than in the acidic stomach juice, particularly for those elements which are more easily re-adsorbed or precipitated under near-neutral conditions (i.e., $\mathrm{Pb}$ ). The use in a risk assessment of bioaccessible concentrations of those elements, as determined in extractions with $\mathrm{HCl}$, would over-estimate the risk although not to the same extent as aqua-regia or similar pseudo-total digestions, in which less than $5 \%$ of the resulting concentrations of $\mathrm{Pb}, \mathrm{Ni}$, and $\mathrm{Cr}$ may be available for absorption in the intestine. Metals in urban particles of natural origin are generally more strongly bound and consequently exhibit a lower bioavailability than those associated with anthropic sources. Lastly, indoor dust presents higher concentrations and higher bioaccessibility than urban soil. As a consequence, risk assessments, which normally integrate dust and soil as one single exposure medium, may gain in accuracy if both sources of exposure were considered separately.

Risk in playgrounds

A large body of knowledge has been developed over the last decades on the exposure of children, the most sensitive segment of the population, to urban particulate materials (Laidlaw and Filippelli 2008; Mielke et al. 1999; Evans et al. 1992). Specifically, some researchers have concentrated their efforts on the chemical composition of playground soil and dust (Ljung et al. 2006a, b; Ng et al. 2003; Wong and Mak 1997; Duggan et al. 1985), since the exposure of children to trace elements in this material is particularly high, relative to other activities and other locations, during games at school breaks and in public playgrounds after school (Roscher et al. 1996). A detailed risk assessment by Dudka and Miller (1999) revealed that the highest risk to children in playgrounds was ingestion of soil particles, followed by dermal absorption. Wong and Mak (1997) carried out a simplified risk assessment, comparing the heavy metal concentrations found in dusts and soils in Hong Kong playgrounds with the Dutch Soil Investigation Levels and concluded that $\mathrm{Pb}$ and $\mathrm{Zn}$ might pose a health hazard for children. In contrast, De Miguel et al. (2007) collected samples from the top $2 \mathrm{~cm}$ of the sandy substrate in Madrid municipal playgrounds and found that the element of most concern was As in terms of both carcinogenic and non-carcinogenic risk. However, in playgrounds with chromated copper arsenate (CCA)-treated equipment, children may experience a much higher exposure to As than that found in Madrid, as a result of not only soil ingestion and dermal absorption but more importantly, direct oral ingestion of dislodgable arsenic from wood (Hemond and SoloGabriele 2004; Stilwell and Gorny 1997).

Despite numerous studies attempting to quantify relevant exposure factors for children during playing activities, there is significant variability amongst their results (Hemond and Solo-Gabriele 2004; USEPA 2002; Buchardt-Boyd et al. 1999; Evans et al. 1992) 
Fig. 3 Simplified representation of the urban geochemical cycle

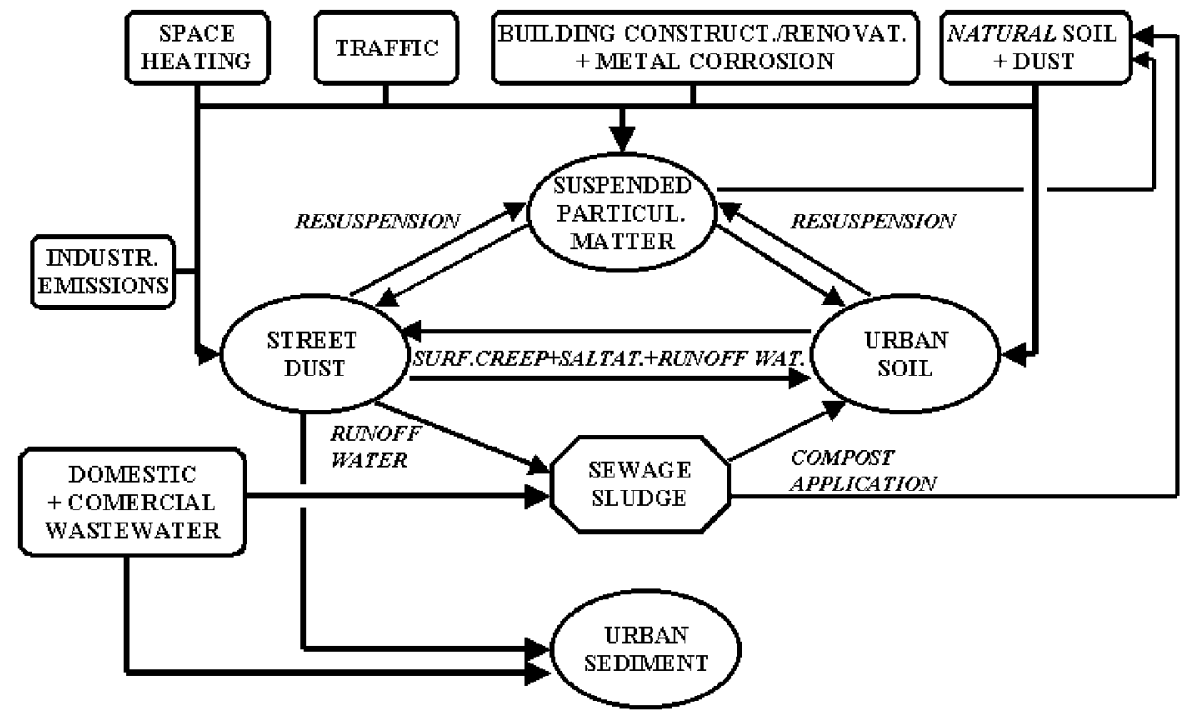

reflecting the difficulties involved. Exposure frequency, e.g., cannot be directly extrapolated from one survey to another since playing habits and time spent outdoors may differ substantially from one region to another. Additionally, quantitative estimates of the toxic potency of elements and compounds found in urban matrices are being constantly reviewed with considerable changes in their values and sometimes even in the threshold or non-threshold behavior of the toxicant.

Although these considerations suggest that risk assessments in urban environments should be interpreted with caution, they do not invalidate their potential in being able to identify the contaminants of most concern and the most relevant routes of exposure.

\section{Urban geochemical cycles}

Having established the importance of studying the geochemistry of urban environments in terms of the risk imposed by potentially increasing concentrations of hazardous elements in concert with population increase (cf. Charlesworth et al. 2003) the question of managing the risk arises. In order to apply management strategies, it is important to be able to predict where "hot spots" of contamination are likely to occur. Hence there have been many attempts to model urban geochemical cycles, with varying degrees of success.

Figure 3 shows a simplified model of the way in which trace elements circulate between different urban media (i.e., atmospheric aerosol, street dust, urban soil, and urban sediment). They can do so in aqueous solution, and, most importantly, in association with particulate solids, the finest fraction of which is especially relevant for two reasons:

1. Particles with a diameter $<100 \mu \mathrm{m}$ can be resuspended and are easily transferred between soil, street dust, and atmospheric aerosol.

2. Particles in the silt-clay size range have the highest capacity to bind, and therefore transport, trace elements.

As well as trace elements, urban particulate material always includes a certain proportion of natural material, such as particles of natural soil or airborne particles from outside the city limits. Although the exact chemical makeup of this component is closely related to the type of geological material in and around the city, it is probably the major source of the $\mathrm{Ce}, \mathrm{Ga}, \mathrm{La}, \mathrm{Th}$ and $\mathrm{Y}$ found in urban environments. This association of "natural" trace elements is surprisingly stable in that it is found in cities of different urban characteristics, e.g., Madrid, Oslo, and Ostrava (De Miguel et al. 1999) and has also been found all through the urban cycle: in the atmospheric aerosol, in street dust, in the urban soil, and in urban sediments.

Incomplete descriptions of the urban cycle of some elements have already been reported, as in De Miguel et al. (1998) who followed the fate of $\mathrm{Ag}$ in the city of Madrid. Silver can be introduced as a component 
of medical (X-ray plates, dental alloys), commercial (photographic film) or industrial materials (highcapacity $\mathrm{Ag}-\mathrm{Zn}$ and $\mathrm{Ag}-\mathrm{Cd}$ batteries). Disposal of these materials ultimately results in the release and transport of $\mathrm{Ag}$ in urban waters. As these waste waters are treated in urban wastewater treatment plants, Ag becomes concentrated in the sludge produced during the treatment process, where it reaches values close to $45 \mu \mathrm{g} \mathrm{g}^{-1}$. This sludge is in turn processed into a compost that is widely used by municipalities as soil amendment in parks and gardens. Silver is further concentrated in the compost (up to $50-70 \mu \mathrm{g} \mathrm{g}^{-1}$ ), most likely due to the loss of mass during fermentation in the piles of maturing sewage sludge. The application of this compost on urban soil re-introduces Ag, resulting in median concentrations of this element nearly five times higher in compost amended soils than in nonamended urban soils. Data published by De Miguel et al. (2005) strongly suggest that not all the Ag that enters the urban water system is confined in sewage sludge to re-enter the urban cycle. Concentrations of up to $16 \mu \mathrm{g} \mathrm{g}^{-1}$ and a strong association with typically anthropogenic elements like $\mathrm{Cu}, \mathrm{Pb}$, and $\mathrm{Zn}$ in the sediments of the River Manzanares that runs through Madrid implies that a fraction of this $\mathrm{Ag}$ is stored in the river sediments.

Charlesworth et al. (2000) envisaged the urban particulate environment as a "cascade" whereby sources included point sources, fluvial bed sediments, and polluted dusts. These were then transported in water via suspended sediment in storm sewers, rivers and streams, or in the atmosphere and were then eventually deposited in gully pots or urban lakes. However, the urban environment is complex (or "frustrating" Charlesworth et al. 2000, p. 356) with a wide variety of processes impacting on the physicochemical characteristics of the particles as they move around the cascade and very few relationships were found between the geochemical and geophysical parameters making up the fingerprint of sediment taken from the individual compartments of the cascade.

\section{Future trends and concluding remarks}

Urban geochemistry will have to keep growing in pace with the increase in urban population around the world, soon becoming "the most dominant human habitat in history" (Wong et al. 2006, p. 12). As a subject, it has rapidly grown in depth and complexity over the last three decades, having the capacity to bring about fundamental changes in urban life, as demonstrated by the gradual phasing out of leaded petrol after decades of geochemical research on urban $\mathrm{Pb}$. However, many studies have shown that while emission of such elements as $\mathrm{Pb}$ have reduced, solid deposits on the surfaces of streets and in people's homes still retain a record of past contamination which can pose a risk to the city's inhabitants, particularly children.

The improvement of already existing analytical techniques and the advent of new ones have greatly widened the scope of urban geochemical research. The current routine use of ICP-AES, ICP-MS, and GC-MS has facilitated previously laborious multielemental determinations, and has brought detection limits down to the levels required to quantify the low concentrations of trace elements and organic compounds collected in cascade-impactor filters, dissolved in street runoff or recovered in the individual fractions of sequential extraction procedures. In the foreseeable future, therefore, it is likely that one of the major research interests will concern the adaptation and development of risk-assessment tools for urban environments, the exploration of which has already led to the development of the subject of medical geology (Bowman et al. 2003). Geochemistry already plays a relevant role in risk analysis, as it helps to evaluate how a contaminant can partition between different phases and migrates from its source to the potential receptors. In turn, risk assessment provides a means to quantify the severity of the adverse health effects associated with the toxic elements and compounds that urban geochemistry investigates. Urban geochemistry and risk assessment are currently employed together to characterize "brownfields", and it seems that the next development will probably involve evaluation of whole urban areas from an environmental risk perspective (Beer and Ricci 1999).

However, a large number of questions about the urban environment have yet to be adequately or completely addressed. The modeling of the urban environment in terms of geochemical cycles, e.g., is difficult due to the complex mixtures of materials constantly undergoing change. The challenges of this 
"multicomponent, multiphase" environment (Turner 1992) are likely to keep urban geochemists busy for some time to come.

\section{References}

Abrahams, P. W. (2002). Soils: Their implications to human health. The Science of the Total Environment, 291, 1-32.

Allott, R. W., Hewitt, C., \& Kelly, M. R. (1990). The environmental half-lives and mean residence times of contaminants in dust for an urban environment: Barrow-in-furness. Science of the Total Environment, 93, 403-410.

Arditsoglou, A., Petaloti, C., Terzi, C., Sofoniou, M., \& Samara, C. (2004). Size distribution of trace elements and polycyclic aromatic hydrocarbons in fly ashes generated in Greek lignite-fired power plants. Science of the Total Environment, 323(1-3), 153-167.

Banerjee, A. D. K. (2003). Heavy metal levels and solid-phase speciation in street dust of Delhi, India. Environmental Pollution, 123, 95-105.

Barbante, C., Veysseyre, A., Ferrari, C., Van de Velde, K., Morel, C., Capodaglio, G., et al. (2001). Greenland snow evidence of large-scale atmospheric contamination for platinum, palladium and rhodium. Environmental Science and Technology, 35, 835-839.

Beer, T., \& Ricci, P. F. (1999). A quantitative risk assessment method based on population and exposure distributions using Australian air quality data. Environment International, 25, 887-898.

Begum, B. A., Biswas, S. K., \& Hopke, P. K. (2007). Source apportionment of air particulate matter by chemical mass balance (CMB) and comparison with positive matrix factorization (PMF) model. Aerosol and Air Quality Research, 7(4), 446-468.

Berti, W. R., \& Jacobs, L. W. (1998). Distribution of trace elements in soil from repeated sewage sludge applications. Journal of Environment Quality, 27, 1280-1286.

Biasioli, M., Grčman, H., Kralj, T., Díaz-Barrientos, E., \& Ajmone-Marsan, F. (2007). Potentially toxic elements contamination in urban soils: A comparison of three European cities. Journal of Environment Quality, 36, 70-79.

Birke, M., \& Rauch, U. (2000). Urban geochemistry: Investigations in the Berlin metropolitan area. Environmental Geochemistry and Health, 22, 233-248.

Bityukova, L., Shogenova, A., \& Birke, M. (2000). Urban geochemistry: A study of element distributions in the soils of Tallinn (Estonia). Environmental Geochemistry and Health, 22, 173-193.

Bollhofer, A., \& Rosman, K. J. R. (2000). Isotopic source signatures for atmospheric lead: The southern hemisphere. Geochimica et Cosmochimica Acta, 64, 3251-3262.

Boni, C., Caruso, E., Cereda, E., Lombardo, G., Braga Marcazzan, G. M., \& Redaelli, P. (1988). Particulate matter elemental characterization in urban areas: Pollution and source identification. Journal of Aerosol Science, 19, 1271-1274.

Bowman, C. A., Bobrowsky, P. T., \& Selinus, O. (2003). Medical geology: new relevance in the earth sciences. Episodes, 270-278.
Boyd, H. B., Pedersen, F., Cohr, K. H., Damborg, A., Jakobsen, B. M., Kristensen, P., et al. (1999). Exposure scenarios and guidance values for urban soil pollutants. Regulatory Toxicology and Pharmacology, 30, 197-208.

Buchardt-Boyd, H., Pedersen, F., Cohr, K. H., Damborg, A., Jakobsen, B. M., Kristensen, P., et al. (1999). Exposure scenarios and guidance values for urban soil pollutants. Regulatory Toxicology and Pharmacology, 30, 197-208.

CDC (Centers for Disease Control and Prevention). (2007). Advisory committee on childhood lead poisoning prevention. MMWR Recommendations, 56(RR-80), 1-16.

Charlesworth, S. M., Booty, C., \& Beasant, J. (2007). Monitoring the atmospheric deposition of particulate-associated urban contaminants, Coventry, UK. In G. M. Morrison \& S. Rauch (eds.), Proceedings of the 8th Highway and Urban Environment Symposium Series: Alliance for Global Sustainability Bookseries (Vol. 12, pp. 155-165).

Charlesworth, S. M., Everett, M., McCarthy, R., Ordóñez, A., \& De Miguel, E. (2003). A comparative study of heavy metal concentration and distribution in deposited street dusts in a large and a small urban area: Birmingham and Coventry, West Midlands, UK. Environment International, 29(5), 563-573.

Charlesworth, S. M., \& Foster, I. D. L. (2005). Gamma-emitting radionuclide and metallic elements in urban dusts and sediments, Coventry, UK: Implications of dosages for dispersal and disposal. Mineralogical Magazine, 69(5), $759-767$.

Charlesworth, S. M., \& Lees, J. A. (1999). Particulate-associated heavy metals in the urban environment: Their transport from source to deposit, Coventry, UK. Chemosphere, 39, 833-848.

Charlesworth, S. M., Ormerod, L. M., \& Lees, J. A. (2000). Tracing sediments within urban catchments using heavy metal, mineral magnetic and radionuclide signatures. In I. D. L. Foster (Ed.), Tracers in geomorphology. New York: Wiley.

Chattopadhyay, G., Lin, K. C. P., \& Feitz, A. J. (2003). Household dust metal levels in the Sydney metropolitan area. Environmental Research, 93, 301-307.

Chen, J., Tan, M., Li, Y., Zhang, Y., Lu, W., Tong, Y., et al. (2005). A lead isotope record of Shanghai atmospheric lead emissions in total suspended particles during the period of phasing out of leaded gasoline. Atmospheric Environment, 39, 1245-1253.

Choi, J., Fuentes, M., \& Reich, B. J. (2009). Spatial-temporal association between fine particulate matter and daily mortality. Computational Statistics \& Data Analysis, 53(8), 2989-3000.

Chon, H. T., Kim, K. W., \& Kim, J. Y. (1995). Metal contamination of soils and dusts in Seoul metropolitan city, Korea. Environmental Geochemistry and Health, 17, 139-146.

Cornille, P., Maenhaut, W., \& Pacyna, J. M. (1990). Sources and characteristics of the atmospheric aerosol near Damascus, Syria. Atmospheric Environment, 24A, 1083-1093.

Crosby, D. G. (1998). Environ toxicology and chemistry (p. 336). Oxford: Oxford University Press.

Dao, L., Morrison, L., \& Zhang, C. (2009). Spatial variation of urban soil geochemistry in a roadside sports ground in Galway, Ireland. Science of the Total Environment, 408, 1076-1084. 
Davies, D. J. A., Watt, J. M., \& Thornton, I. (1987). Lead levels in Birmingham dusts and soils. Science of the Total Environment, 67, 177-185.

De Miguel, E., Charlesworth, S., Ordóñez, A., \& Seijas, E. (2005). Geochemical fingerprints and controls in the sediments of an urban river: River Manzanares, Madrid (Spain). Science of the Total Environment, 340, 137-148.

De Miguel, E., Iribarren, I., Chacón, E., Ordoñez, A., \& Charlesworth, S. (2007). Risk-based evaluation of the exposure of children to trace elements in playgrounds in Madrid (Spain). Chemosphere, 66, 505-513.

De Miguel, E., Jiménez de Grado, M., Llamas, J. F., MartínDorado, A., \& Mazadiego, L. F. (1998). The overlooked contribution of compost application to the trace element load in the urban soil of Madrid (Spain). Science of the Total Environment, 215, 113-122.

De Miguel, E., Llamas, J. F., Chacón, E., Berg, T., Larssen, S., Røyset, O., et al. (1997). Origin and patterns of distribution of trace elements in street dust. Unleaded petrol and urban lead. Atmospheric Environment, 31, 2733-2740.

De Miguel, E., Llamas, J. F., Chacón, E., \& Mazadiego, L. F. (1999). Sources and pathways of trace elements in urban environments: a multi-elemental qualitative approach. Science of the Total Environment, 235, 355-357.

Defra (Department of Environment, Food and Rural Affairs) and EA (Environment Agency). (2002). Assessment of risks to human health from land contamination: An overview of the development of guideline values and related research. Report CLR7.

Dongarrà, G., Sabatino, G., Triscari, M., \& Varrica, D. (2003). The effects of anthropogenic particulate emissions on roadway dust and Nerium oleander leaves in Messina (Sicily, Italy). Journal of Environmental Monitoring, 5, 766-773.

Drew, H. M. (1975). Metal-based lubricant composition ( $\mathrm{p}$. 332). New Jersey: Noyes Data Corporation.

Droppo, I. G., Irvine, K. N., Murphy, T. P., \& Jaskot, C. (1998). Fractionated metals in street dust of a mixed land use sewershed, Hamilton, Ontario. Hydrology in a Changing Environment III, 383-394 (British Hydrological Society).

Dudka, S., \& Miller, W. P. (1999). Permissible concentrations of arsenic and lead in soils based on risk assessment. Water, Air, and Soil pollution, 113, 127-132.

Duggan, M. J., Inskip, M. J., Rundle, S. A., \& Moorcroft, J. S. (1985). Lead in playground dust and on the hands of schoolchildren. Science of the Total Environment, 44, $65-79$.

Duzgoren-Aydin, N. S. (2007). Sources and characteristics of lead pollution in the urban environment of Guangzhou. The Science of the Total Environment, 385, 182-195.

Duzgoren-Aydin, N. S., \& Weiss, A. L. (2008). Use and abuse of $\mathrm{Pb}$-isotope fingerprinting technique and GIS mapping data to assess lead in environmental studies. Environmental Geochemistry and Health, 30, 577-588.

Duzgoren-Aydin, N.S., Willett, K.L., \& Khan, I.A. (2010). Determination of total and partially extractable solidbound element concentrations using collision/reaction cell inductively coupled plasma-mass spectrometry and their significance in environmental studies. Environ Monit Assess. doi: 10.1007/s10661-010-1317-7.
Edwards, R. D., Yurkow, E. J., \& Lioy, P. J. (1998). Seasonal deposition of housedusts onto household surfaces. Science of the Total Environment, 224, 69-80.

European Committee for Standardization. (1995). EN-71: Safety of toys-part 3: specification for migration of certain elements. British Standard EN 71-3.

Evans, E., Ma, M., Kingston, L., Leharne, S., \& Chowdhry, B. (1992). The speciation pattern of lead in street dusts and soils in the vicinity of two London schools. Environment International, 18, 153-162.

Farfel, M. R., Orlova, A. O., Lees, P. S. J., et al. (2003). A study of urban housing demolitions as sources of lead in ambient dust: Demolition practices and exterior dust fall. Environmental Health Perspectives, 111, 12281234.

Fergusson, J. E., \& Kim, D. (1991). Trace elements in street and house dusts: Sources and speciation. Science of the Total Environment, 100, 125-150.

Fergusson, J. E., \& Ryan, D. E. (1984). The elemental composition of street dust from large and small urban areas related to city type, source and particle size. Science of the Total Environment, 34, 101-116.

Ferreira-Baptista, L., \& De Miguel, E. (2005). Geochemistry and risk assessment of street dust in Luanda, Angola: A tropical urban environment. Atmospheric Environment, $39,4501-4512$.

Foster, I. D. L., \& Charlesworth, S. M. (1996). Heavy metals in the hydrological cycle: trends and explanation. Hydrological Processes, 10, 227-261.

Gatz, D. (1975). Relative contribution of different sources of urban aerosols: application of a new estimation method to multiple sites in Chicago. Atmospheric Environment, 9. 1-18.

Giusquiani, P. L., Gigliotti, G., \& Businelli, D. (1992). Mobility of heavy metals in urban waste-amended soils. Joumal of Environment Quality, 21, 330-335.

Granero, S., \& Domingo, J. L. (2002). Levels of metals in soils of Alcalá de Henares, Spain: human health risks. Environment International, 28, 159-164.

Grzebisz, W., Cieśla, L., Komisarek, J., \& Potarzycki, J. (2002). Geochemical assessment of heavy metals pollution of urban soils. Polish Journal of Environmental Studies, 11(5), 493-499.

Hamel, S. C., Buckley, B., \& Lioy, P. J. (1998). Bioaccessibility of metals in soils for different liquid to solid ratios in synthetic gastric fluid. Environmental Science and Technology, 32, 358-362.

Han, B., Kong, S., Bai, Z., Du, G., Bi, T., Li, X, Shi, G., \& Hu, Y. (2010). Characterization of elemental species in $\mathrm{PM}_{2.5}$ samples collected in four cities of northeast China. Water, Air, \& Soil Pollution, 209(1-4), 15-28.

Harrison, P. R., Draftz, R. G., \& Murphy, W. H. (1974). Identification and impact of Chicago's ambient suspended dust. In Proceedings of 'Atmospheric-Surface Exchange of Particulate and Gaseous Pollutants (1974)', Richland, Washington, 4-6 Sept. 1974. Energy Research and Development Administration symposium series, CONF740921 (pp. 557-570). National Technical Information Service, U.S. Department of Commerce.

Harrison, R. M., Laxen, D. P. H., \& Wilson, S. J. (1981). Chemical associations of lead, cadmium, copper and zinc 
in street dusts and roadside soils. Environmental Science and Technology, 15(11), 1376-1383.

Harrison, R. M., Smith, D. J. T., Pio, C. A., \& Castro, L. M. (1997). Comparative receptor modelling study of airborne particulate pollutants in Birmingham (United Kingdom), Coimbra (Portugal) and Lahore (Pakistan). Atmospheric Environment, 31, 3309-3321.

Harvey, P. G., Spurgeon, A., Morgan, J., Chance, J., \& Moss, E. (1985). A method for assessing hand-to-mouth activity in children as a possible transport route for toxic substances. In: Lekkas, T. D. (ed.). Heavy metals in the environment. International Conference, Athens, 1. CEP Consultants, pp. 436-437.

Hemond, H. F., \& Solo-Gabriele, H. M. (2004). Children's exposure to arsenic from CCA-treated wooden decks and playground structures. Risk Analysis, 24, 51-64.

Henry, R. C. (1987). Current factor analysis receptor models are ill-posed. Atmospheric Environment, 21, 1815-1827.

Hogervorst, J., Plusquin, M., Vangronsveld, J., Nawrot, T., Cuypers, A., Van Hecke, E., et al. (2007). House dust as possible route of environmental exposure to cadmium and lead in the adult general population. Environmental Research, 103(1), 30-37.

Hopke, P. K., Lamb, R. E., \& Natusch, D. F. S. (1980). Multielemental characterisation of urban roadway dust. Environmental Science and Technology, 14, 164-172.

Horvath, H. (2008). Conference on visibility, aerosols, and atmospheric optics, Vienna, September 3-6, 2006. Atmospheric Environment, 42(11), 2569-2570. special issue.

ICRCL. (1987). Guidance on the assessment and redevelopment of contaminated land, 2nd Edn. DETR Publications.

ICRP. (1991). Recommendations of the international commission on radiological protection. ICRP publication 60 . Annals of the ICRP, 21, 1-3.

Imperato, M., Adamo, P., Naimo, D., Arienzo, M., Stanzione, D., \& Violante, P. (2003). Spatial distribution of heavy metals in urban soils of Naples city (Italy). Environmental Pollution, 124, 247-256.

Jiries, A. G., Hussein, H. H., \& Halash, Z. (2001). The quality of water and sediments of street runoff in Amman, Jordan. Hydrological Processes, 15, 815-824.

Kappos, A. D., Bruckmann, P., Eikmann, T., Englert, N., Heinrich, U., Höppe, P., et al. (2004). Health effects of particles in ambient air. International Journal of Hygiene and Environmental Health, 207, 399-407.

Kasparian, J., Frejafon, E., Rambaldi, P., Yu, J., Vezin, B., Wolf, J. P., et al. (1998). Characterization of urban aerosols using SEM-microscopy, X-ray analysis and lidar measurements. Atmospheric Environment, 32, 2957-2967.

Kim, J. Y., Kim, K. W., Ahn, J. S., Ko, I., \& Lee, C. H. (2005). Investigation and risk assessment modelling of $\mathrm{As}$ and other heavy metals contamination around five abandoned metal mines in Korea. Environmental Geochemistry and Health, 27, 193-203.

Kim, J. Y., Myung, J. H., Ahn, J. S., \& Chon, H. T. (1998). Heavy metal speciation in dusts and stream sediments in the Taejon area, Korea. Joumal of Geochemical Exploration, 64, 409-419.

Kowalczyk, G. S., Gordon, G. E., \& Rheingrover, S. W. (1982). Identification of atmospheric particulate sources in Washington, D.C., Using chemical element balances. Environmental Science and Technology, 16, 79-90.

Kupiainen, K. (2007). Road dust from pavement wear and traction sanding. Monograph of Boreal Environment Research, 26, Finnish Environment Institute, Helsinki.

Laidlaw, M., \& Filippelli, G. (2008). Resuspension of urban soils as a persistent source of lead poisoning in children: a review and new directions. Applied Geochemistry, 23, 2021-2039.

Lanphear, B. P., Matte, T. D., Rogers, J., Clickner, R. P., Dietz, B., Bornschein, R. L., et al. (1998). The contribution of lead contaminated house dust and residential soil to children's blood lead levels. Environmental Research, 79, 51-68.

Lee, J. S., Chon, H. T., \& Kim, K. W. (2005). Human risk assessment of $\mathrm{As}, \mathrm{Cd}, \mathrm{Cu}$ and $\mathrm{Zn}$ in the abandoned metal mine site. Environmental Geochemistry and Health, 27, 185-191.

Lee, C. S., Li, X., Shi, W., Cheung, S. C., \& Thornton, I. (2006). Metal contamination in urban, suburban, and country park soils of Hong Kong: A study based on GIS and multivariate statistics. Science of the Total Environment, 356, 45-61.

Leharne, S., Charlesworth, D., \& Chowdry, B. (1992). A survey of metal levels in street dusts in an Inner London neighbourhood. Environment International, 18, 263-270.

Li, X. D., Poon, C. S., \& Liu, P. S. (2001). Heavy metal contamination of urban soils and street dusts in Hong Kong. Applied Geochemistry, 16, 1361-1368.

Lin, J. J., \& Lee, L. C. (2004). Characterization of the concentration and distribution of urban submicron $\left(\mathrm{PM}_{1}\right)$ aerosol particles. Atmospheric Environment, 38(3), $469-475$.

Lin, J. J., \& Tai, H. S. (2001). Concentrations and distributions of carbonaceous species in ambient particles in Kaohsiung City. Taiwan Atmospheric Environment, 35, 2627-2636.

Lin, H., Wheeler, D., Bell, D., \& Wilding, L. (2005). Assessment of soil spatial variability at multiple scales. Ecological Modelling, 182, 271-290.

Linge, K. L. (2008). Methods for investigating trace element binding in sediments. Critical Reviews in Environmental Science and Technology, 38, 165-196.

Ljung, K., Oomen, A., Duits, M., Selinus, O., \& Berglund, M. (2007). Bioaccessibility of metals in urban playground soils. Journal of Environmental Science and Health, 42, 1241-1250.

Ljung, K., Selinus, O., \& Otabbong, E. (2006a). Metals in soils of children's urban environments in the small northern European city of Uppsala. Science of the Total Environment, 366, 749-759.

Ljung, K., Selinus, O., Otabbong, E., \& Berglund, M. (2006b). Metal and arsenic distribution in soil particle sizes relevant to soil ingestion by children. Applied Geochemistry, 21, 1613-1624.

Llamas, J. F., Chacón, E., \& De Miguel, E. (1993). Mapping of trace elements in soils in the province of Madrid. Sampling strategies and analysis of results. In H. J. P. Eijsackers \& T. Hamers (Eds.), Integrated soil and sediment research: A basis for proper protection (p. 763). Dordrecht: Kluwer Academic Publishers. 
Loredo, J., Ordóñez, A., Charlesworth, S., \& De Miguel, E. (2004). Influence of industry on the geochemical urban environment of Mieres (Spain) and associated health risk. Environmental Geochemistry and Health, 25(3), 307-323.

Lux, W. (1986). Schwermetallgehalte und -isoplethen in Böden, subhydrischen Ablagerung und Pflanzen im Südosten Hamburgs. Hamburger Bodenkundliche Arbeiten $5,249$.

Madrid, F., Biasioli, M., \& Ajmone-Marsan, F. (2008). Availability and bioaccessibility of metals in fine particles of some urban soils. Archives of Environmental Contamination and Toxicology, 55, 21-32.

Madrid, L., Díaz-Barrientos, E., \& Madrid, F. (2002). Distribution of heavy metal contents of urban soils in park of Seville. Chemosphere, 49, 1301-1308.

Manta, D. S., Angelone, M., Bellanca, A., Neri, R., \& Sprovieri, M. (2002). Heavy metals in urban soils: a case study from the city of Palerma (Sicily), Italy. Science of the Total Environment, 300, 229-243.

Mazzei, F., D'Alessandro, A., Lucarelli, F., Nava, S., Prati, P., Valli, G., et al. (2008). Characterisation of particulate matter sources in an urban environment. Science of the Total Environment, 401, 81-89.

Mielke, H. W., Gonzales, C. R., Smith, M. K., \& Mielke, P. W. (1999). The urban environment and children's health: soils as an integrator of lead, zinc and cadmium in New Orleans, Louisiana, USA. Environmental Research (Section A), 81, 117-129.

Moldovan, M., Palacios, M. A., Gómez, M. M., Morrison, G., Rauch, S., McLeod, C., et al. (2002a). Environmental risk of particulate and soluble platinum group elements released from gasoline and diesel engine catalytic converters. Science of the Total Environment, 296, 199-208.

Moldovan, M., Rauch, S., Gómez, M., Palacios, M. A., \& Morrison, G. M. (2002b). Bioaccumulation of palladium, platinum and rhodium from urban particulates and sediments by the freshwater isopod Asellus aquaticus. Water Research, 35, 4175-4183.

Möller, A., Muller, H., Abdullah, A., Abdelgawad, G., \& Utermann, J. (2005). Urban soil pollution in Damascus, Syria: Concentrations and patterns of heavy metals in the soils of the Damascus Ghouta. Geoderma, 124, 63-71.

Morton-Bermea, O., Hernández-Álvarez, E., González-Hernández, G., Romero, F., Lozano, R., \& Beramendi-Orosco, L. E. (2008). Assessment of heavy metal pollution in urban topsoils from the metropolitan area of Mexico City. Joumal of Geochemical Exploration, 101, 218-224.

Navas, A., \& Machín, J. (2002). Spatial distribution of heavy metals and arsenic in soils of Aragón (northeast Spain): Controlling factors and environmental implications. Applied Geochemistry, 17, 961-973.

Ng, S. L., Chan, L. S., Lam, K. C., \& Chan, W. K. (2003). Heavy metals and magnetic properties of playground dust in Hong Kong. Environmental Monitoring and Assessment, 89, 221-232.

Nicholson, K. W. (1988). A review of particle resuspension. Atmospheric Environment, 22, 2639-2651.

Norra, S., Lanka-Panditha, M., Kramar, U., \& Stüben, D. (2006). Mineralogical and geochemical patterns of urban surface soils, the example of Pforzheim, Germany. Applied Geochemistry, 21, 2064-2081.
Oomen, A. G., Hack, A., Minekus, M., Zeijdner, E., Cornelis, C., Schoeters, G., et al. (2002). Comparison of five in vitro digestion models to study the bioaccessibility of soil contaminants. Environmental Science and Technology, 36, 3326-3334.

Oomen, A. G., Rompelberg, C. J. M., Bruil, M. A., Dobbe, C. J. G., Pereboom, D. P. K. H., \& Sips, A. J. A. M. (2003). Development of an in vitro digestion model for estimation of bioaccessibility of soil contaminants. Archives of Environmental Contamination and Toxicology, 44, 281287.

Ordóñez, A., Loredo, J., De Miguel, E., \& Charlesworth, S. M. (2003). Distribution of heavy metals in the street dusts and soils of an industrial city in northern Spain. Archives of Environmental Contamination and Toxicology, 44, 160-170.

Pacyna, J. M. (1983). Trace element emission from anthropogenic sources in Europe. Technical report. 10/82. Norsk Institutt for Luftforskning. Ref. 24781, p. 107.

Pacyna, J. M. (1991). Chemical tracers of the origin of arctic air pollution. In: Sturges, W. T. (ed.), Pollution of the arctic atmosphere. Environmental management series (J. Cairns Jr. \& R. M. Harrison, Eds.). Amsterdam: Elsevier.

Palacios, M. A., Gómez, M., Moldovan, M., \& Gómez, B. (2000). Assessment of environmental contamination risk by $\mathrm{Pt}, \mathrm{Rh}$ and $\mathrm{Pd}$ from automobile catalyst. Microchemical Journal, 67, 105-113.

Paterson, E., Sanka, M., \& Clark, L. (1996). Urban soils as pollutant sinks-a case study from Aberdeen, Scotland. Applied Geochemistry, 11, 129-131.

Patra, A., Colvile, R., Arnold, S., Bowen, E., Shallcross, D., Martin, D., et al. (2008). On street observations of particulate matter movement and dispersion due to traffic on an urban road. Atmospheric Environment, 42, 3911-3926.

Perez-Santana, S., Pomares Alfonso, M., Villanueva Tagle, M., Peña Icart, M., Brunori, C., \& Morabito, R. (2007). Total and partial digestion of sediments for the evaluation of trace element environmental pollution. Chemosphere, 66 , 1545-1553.

Pope, C. A., Ezzati, M., \& Dockery, W. D. (2009). Fine particulate air pollution and life expectancy in the United States. The New England Journal of Medicine, 360 , 376-386.

Pryor, S. C., Barthelmie, R. J., Schoof, J. T., Binkowski, F. S., Delle Monache, L., \& Stull, R. (2008). Modeling the impact of sea-spray on particle concentrations in a coastal city. Science of the Total Environment, 391, 132-142.

Rasmussen, P. E., Beauchemin, S., Nugent, M., Dugandzic, R., Lanouette, M., \& Chénier, M. (2008). Influence of matrix composition on the bioaccessibility of copper, zinc, and nickel in urban residential dust and soil. Human and Ecological Risk Assessment, 14, 351-371.

Ravindra, K., Bencs, L., \& Van Grieten, R. (2004). Platinum group elements in the environment and their health risk. Science of the Total Environment, 318, 1-43.

RIVN (Dutch National Institute for Public Health and the Environment) (2006). How can information on oral bioavailability improve human health risk assessment for lead contaminated soils? RIVM report 711701042.

Roscher, E., Liebl, B., Schwegler, U., Schmied, R., \& Kerscher, G. (1996). Richtwerte für polyzyklische aromatische 
Kohlenwasserstoffe im Boden von KinderspielplätzenAbleitungskriterien und Empfehlunge. Gesundheitswesen, $58,470-476$.

Rose, A., Juggins, S., Watt, J., \& Battarbee, R. (1994). Fuel type characterization of spheroidal carbonaceous particles using surface chemistry. Ambio, 23, 296-299.

Ruby, M., Davis, A., Schoof, R., Eberle, S., \& Sellstone, C. M. (1996). Estimation of lead and arsenic bioavailability using a physiologically based extraction test. Environmental Science and Technology, 29, 422-430.

Ruby, M., Schoof, R., Brattin, W., Goldade, M., Post, G., Harnois, M., et al. (1999). Advances in evaluating the oral bioavailability of inorganics in soil for use in human health risk assessment. Environmental Science and Technology, 33, 3697-3705.

Rundle, S. A., \& Duggan, M. J. (1986). Lead pollution from the external redecoration of old buildings. Science of the Total Environment, 57, 181-190.

Rundle, S. A., Inskip, M. J., Duggan, M. J., \& Moorcroft, J. S. (1985). Lead-in-dust on children's hands. In: Lekkas, T. D. (ed.). Heavy metals in the environment. Intemational Conference, Atenas, CEP Consultants, 1, pp. 457-459.

Sadiq, M., \& Mian, A. A. (1994). Nickel and vanadium in air particulates at Dharahn (Saudi Arabia) during and after the Kuwait oil fires. Atmospheric Environment, 28, 22492253.

Sansalone, J., Koran, J., Buchberger, J., \& Smithson, G. (1998). Physical characteristics of highway solids transported during rainfall. Journal of Environmental Engineering, 124(5), 427-440.

Sastre, J., Sahuquillo, A., Vidal, M., \& Rauret, G. (2002). Determination of $\mathrm{Cd}, \mathrm{Cu}, \mathrm{Pb}$ and $\mathrm{Zn}$ in environmental samples: Microwave-assisted total digestion versus aqua regia and nitric acid extraction. Analytica Chimica Acta, $462(1), 59-72$.

Schäfer, J., Eckhardt, J. D., Berner, Z. A., \& Stüben, D. (1999). Time-dependant increase of traffic-emitted platinum group elements (PGE) in different environmental compartments. Environmental Science and Technology, 33, 3166-3170.

Schroder, J. L., Basta, T., Si, J., Casteel, S. W., Evand, T., \& Payton, M. (2003). In vitro gastrointestinal method to estimate relative bioavailable cadmium in contaminated soil. Environmental Science and Technology, 37, 13651370 .

Schwar, M. J. R., Moorcroft, J. S., Laxen, D. P. H., Thompson, M., \& Armorgie, C. (1988). Baseline metal-in-dust concentrations in Greater London. Science of the Total Environment, 68, 25-43.

Serrano-Belles, C., \& Leharne, S. (1997). Assessing the potential for road release from road dust and soils. Environmental Geochemistry and Health, 19, 89-100.

Sharaf, E., Abdel-Shakour, A., Amer, M., Abou-Donia, M. A., \& Khatab, N. (2008). Evaluation of children's blood lead level in Cairo, Egypt. American-Eurasian Joumal of Agricultural \& Environmental Sciences, 3(3), 414-419.

Shepherd, K. A., Ellis, P. A., \& Rivett, M. O. (2006). Integrated understanding of urban land, groundwater, baseflow and surface-water quality-The City of Birmingham, UK. Science of the Total Environment, 360, 180-195.
Shi, G., Chen, Z., Xu, S., Zhang, J., Wang, L., Bi, C., et al. (2008). Potentially toxic metal contamination of urban soils and roadside dust in Shanghai, China. Environmental Pollution, 156(2), 251-260.

Stigliani, W. M. \& Anderberg, S. (1991). Industrial metabolism and the Rhine Basin. Options, Sept. 1991.

Stilwell, D. E., \& Gorny, K. D. (1997). Contamination of soil with copper, chromium, and arsenic under decks built from pressure treated wood. Environmental Contamination and Toxicology B, 58, 22-29.

Sturges, W. T., \& Harrison, R. M. (1986). Bromine: Lead ratios in airborne particles from urban and rural sites. Atmospheric Environment, 20, 577-588.

Sutherland, R. A. (2002). Comparison between non residual Al, $\mathrm{Co}, \mathrm{Cu}, \mathrm{Fe}, \mathrm{Mn}, \mathrm{Ni}, \mathrm{Pb}$ and $\mathrm{Zn}$ released by a three-step sequential extraction procedure and a dilute hydrochloric acid leach for soil and road deposited sediment. Applied Geochemistry, 17, 353-365.

Sutherland, R. A., Day, J. P., \& Bussen, J. O. (2002). Lead concentrations, isotope ratios and source apportionment in road deposited sediments, Honolulu, Oahu, Hawaii. Water, Air, and Soil pollution, 142, 165-186.

Tam, N. F. Y., \& Yao, M. W. Y. (1999). Three digestion methods to determine concentrations of $\mathrm{Cu}, \mathrm{Zn}, \mathrm{Cd}, \mathrm{Ni}$, $\mathrm{Pb}, \mathrm{Cr}, \mathrm{Mn}$, and $\mathrm{Fe}$ in mangrove sediments from Sai Keng, Chek Keng, and Sha Tau Kok, Hong Kong. Bulletin of Environmental Contamination and Toxicology, 62, $708-716$.

Tessier, A., Campbell, P. G. C., \& Bisson, M. (1979). Sequential extraction procedure for the speciation of particulate trace metals. Analytical Chemistry, 51, 844-851.

Thornton, I. (1991). Metal contamination of soils in urban areas. In P. Bullock \& P. J. Gregory (Eds.), Soils in urban environment (pp. 47-75). Oxford: Blackwell.

Tijhuis, L., Brattli, B., \& Sæther, O. M. (2002). A geochemical survey of topsoil in the city of Oslo, Norway. Environmental Geochemistry and Health, 24, 67-94.

Tomza, U. (1984). Trace elements in the atmospheric aerosol at Katowice, Poland. Technical Report. Instituut voor Nucleaire Wetenschappen, Rijksuniversiteit Gent, Gent, Belgium.

Tong, S. T. Y. (1998). Indoor and outdoor household dust contamination in Cincinnati, Ohio, USA. Environmental Geochemistry and Health, 20(3), 123-133.

Tong, S. T. Y., \& Lam, K. C. (2000). Home sweet home? A case study of household dust contamination in Hong Kong. Science of the Total Environment, 256(2-3), 115-123.

Turner, D. R. (1992). The chemistry of metal pollutants in water. In R. A. Harrison (Ed.), Pollution: causes, effects and controls. Cambridge: Royal Society of Chemistry.

Turner, A., \& Simmonds, L. (2006). Elemental concentrations and metal bioaccessibility in UK household dust. Science of the Total Environment, 371, 74-81.

USEPA (US Environmental Protection Agency). (1994). Method-3051. Microwave-assisted acid digestion of sediments, sludges, soils and oils. Washington, DC.

USEPA (US Environmental Protection Agency). (1996). Method-3052. Microwave-assisted acid digestion of siliceous and organically based matrices. Washington, DC. 
USEPA (US Environmental Protection Agency). (1997). Method-3051A. Microwave-assisted acid digestion of sediment, sludges, soils and oils. Washington, DC.

USEPA (US Environmental Protection Agency). (2002). ChildSpecific Exposure Factors Handbook. EPA-600-P-00$002 B$. National Center for Environmental Assessment, US Environmental Protection Agency. Washington, DC, from http:/cfpub.epa.gov/ncea/cfm/recordisplay.cfm?Print Version $=$ Trueanddeid $=52047$.

Van Dingenen, R., Raes, F., Putaud, J. P., Baltensperger, U., Charron, A., Facchini, M. C., et al. (2004). A European aerosol phenomenology-1: Physical characteristics of particulate matter at kerbside, urban, rural and background sites in Europe. Atmospheric Environment, 38, 2561-2577.

Vermette, S. J., Irvine, K. N., \& Drake, J. J. (1991). Temporal variability of the elemental composition in urban street dust. Environmental Monitoring and Assessment, 18, 69-77.

Viana, M., Querol, X., Alastuey, A., Gil, J. I., \& Menéndez, M. (2006). Identification of PM sources by principal component analysis (PCA) coupled with wind direction data. Chemosphere, 65, 2411-2418.

Wadge, A., Hutton, M., \& Peterson, P. J. (1986). The concentrations and particle size relationships of selected trace elements in fly ashes from U.K. coal-fired power plants and a refuse incinerator. Sci Total Environ, 13-27.

Wang, W. H., Wong, M. H., Leharne, S., \& Fisher, B. (1998). Fractionation and biotoxicity of heavy metals in urban dusts from Hong Kong and London. Environmental Geochemistry and Health, 20, 185-198.

Wang, S. X., Zhao, Y., Chen, G. C., Wang, F., Aunan, K., \& Hao, J. M. (2008). Assessment of population exposure to particulate matter pollution in Chongqing, China. Environmental Pollution, 153, 247-256.

Warren, R. S., \& Birch, P. (1987). Heavy metal levels in atmospheric particulates, roadside dust and soil along a major urban highway. Science of the Total Environment, $59,253-256$.

Watt, J., Thornton, I., \& Cotter-Howells, J. (1993). Physical evidence suggesting the transfer of soil $\mathrm{Pb}$ into young children via hand-to-mouth activity. Applied Geochemistry, Suppl. Issue, 2, 269-272.

Wcislo, E., Ioven, D., Kucharski, R., \& Szdzuj, J. (2002). Human health risk assessment case study: an abandoned metal smelter site in Poland. Chemosphere, 47, 507-515.
Widory, D., Roy, S., Le Moullec, Y., Goupil, G., Cocherie, A., \& Guerrot, C. (2004). The origin of atmospheric particles in Paris: a view through carbon and lead isotopes. Atmospheric Environment, 38, 953-961.

Wilcke, W., Müller, S., Kanchanakool, N., \& Zech, W. (1998). Urban soil contamination in Bangkok: heavy metal and aluminium partitioning in topsoils. Geoderma, 86, 211-228.

Williams, M. (2004). Air pollution and policy-1952-2002. Science of the Total Environment, 334-335, 15-20.

Wong, C. S. C., Li, X., \& Thornton, I. (2006). Urban environmental geochemistry of trace metals. Environmental Pollution, 142, 1-16.

Wong, J. W. C., \& Mak, K. (1997). Heavy metal pollution in children's playgrounds in Hong Kong and its health implications. Environmental Technology, 18, 109-115.

Wong, E. Y., Shirai, J. H., Garlock, T. J., \& Kissel, J. C. (2000). Survey of selected activities relevant to exposures to soils. Bulletin of Environmental Contamination and Toxicology, 65, 443-450.

Yesilonis, I. D., Pouyat, R., \& Neerchal, K. (2008). Spatial distribution of metals in soils in Baltimore, Maryland: role of native parent material, proximity to major roads, housing age and screening guidelines. Environmental Pollution, 156, 723-731.

Yuan, C. S., Cheng, S. W., Hung, C. H., \& Yu, T. Y. (2003). Influence of operating parameters on the collection efficiency and size distribution of street dust during street scrubbing. Aerosol and Air Quality Research, 3(1), 75-86.

Zhao, P., Feng, Y., Zhu, T., \& Wu, J. (2006). Characterizations of resuspended dust in six cities of North China. Atmospheric Enviranment, 40, 5807-5814.

Zhu, B. Q., Chen, Y. W., \& Chang, X. Y. (2003). Application of $\mathrm{Pb}$ isotopic mapping to environment evaluation in China. Chemical Speciation and Bioavailability, 14, $49-56$.

Zhu, B. Q., Chen, Y. W., \& Peng, J. H. (2001). Lead isotope geochemistry of urban environment in the Pearl River Delta. Applied Geochemistry, 16, 409-417.

Zou, B., Wilson, J. G., Zhand, F. B., \& Zeng, Y. (2009). Spatially differentiated and source-specific population exposure to ambient urban air pollution. Atmospheric Environment, 43(26), 3981-3988. 